\title{
SPOORWEE EN HAWENS IN AFRIKA MET SPESIALE VERWYSING NA SUID-AFRIKA
}

\section{Inleiding:}

Die mens en alle aardse goedere is uiteraard gebonde aan ruimte en tyd. Hierdie gebondenheid beperk die maatskap. like, kulturele en ekonomiese ontwikkeling van die mens en dit is die taak en funksie van vervoer om hierdie gebondenheid te oorbrug deur mense en goedere van een plek na ' $n$ ander te verskuif in die mins moontlike tyd. Uit die drang van die mens tot verbetering van homself en sy omgewing het dan ook die moderne vervoerstelsels van die wêreld ontstaan.

Waar vervoer 'n noodsaaklike voorvereiste vir 'n moderne volkshuishouding is, is dit ook eweneens waar dat die ontwikkeling van spoorweë die moderne tydsvak van die geïndustrialiseerde ekonomie ingelui het en inderdaad ook stimulus en stukrag verleen het aan die proses van industrialisasie. So verklaar W. W. Rostow: „The introduction of the railroad has been historically the most powerful single initiator of takeoffs (of economic growth)". Ook in Afrika en Suid-Afrika wat relatief swak bedeeld is sover dit bevaarbare binnelandse riviere aanbetref, was ekonomiese ontwikkeling eers moontlik nadat spoorvervoer beskikbaar was.

As gevolg van die groot kapitaalbelegging wat gepaard gaan met die bou van 'n spoorlyn is dit aan die anderkant nodig dat 'n redelike vraag na vervoer tussen twee punte moet bestaan voor 'n spoorverbinding gebou kan word. 'n Spoorverbinding kan dus nie tussen twee punte waar daar geen of min vraag na vervoer bestaan, gebou word met die hoop dat die beskikbaarheid van die spoorvervoer ekonomiese ontwikkeling sal stimuleer en sodoende spoorvervoer sal opwek nie. Die bou van spoorlyne word dus bepaal deur die geografiese verspreiding van landbou- en bosbougebiede, grondstowwe, kragbronne, geïndustrialiseerde gebiede en markte.

Afrika is een van die groot vastelande en beslaan ongeveer $20 \%$ van die aarde se landoppervlak. In teenstelling hiermee is die bevolking van Afrika ongeveer 240 miljoen wat slegs $8 \%$ van die wêreldbevolking verteenwoordig. Verder is die grootste deel van die bevolking in enkele gebiede gekonsen- 
treer, nl. die Nyldelta, die kusgebiede van Tunisië tot by Marokko, die kusgebiede van Nigerië, die noordelike gebied om die Victoriameer, Rwanda, Burundi en die Randse gebied. Oor die res van die vasteland is die bevolking baie yl versprei. meestal minder as 5 per vierkante myl.

Daar is slegs drie stede in Afrika met ' $n$ bevolking van meer as 1 miljoen, nl. Kaïro, Alexandrië en Johannesburg, terwyl daar ' $n$ verdere 14 stede is met meer as 'n kwart miljoen inwoners, nl. Algiers, Kaapstad, Casablanca, Tunis, Durban, Ibadan, Pretoria, Addis Ababa, Oran, Lagos, Akkra, Leopoldville, Port Elizabeth en Nairobi. Hierdie stede wat nie aan die kus geleë is nie is verbind met die kus met 'n spoorlyn.

Die enigste geïndustrialiseerde gebied in Afrika wat nie by die kus geleë is nie, is die Randse kompleks. As gevolg hiervan is daar dan ook in Suid-Afrika 'n hele netwerk van spoorlyne wat aan die Rand konvergeer, in teenstelling met die res van Afrika waar daar net verbindingslyne en geen netwerk bestaan nie.

Met uitsondering van die woestyngebied vind landboubedrywighede in alle dele van Afrika plaas. As gevolg van die feit dat slegs $7.9 \%$ van die totale oppervlakte van die vasteland as bewerkbaar geklassifiseer kan word, is die meeste van die landbouproduksie net vir eie gebruik. Behalwe in tropiese reënwoud- en woestynstreke kom veeteelt in alle gebiede voor wat vry is van tsetsevlieg.

Ongeveer $24 \%$ van die oppervlakte van Afrika is bebos en die grootste produksie van hardehout kom voor aan die weskus van ekwatoriaal-Afrika.

Vir krag is Afrika merendeels afhanklik van steenkool te Witbank, Wankie, Nigerië en Tanzanië; uraan aan die Rand, Katanga en Nigerië; hidro-elektriese krag van die Kariba-skema, Oued-Djen-Djen in Algerië, Inga en Nzilo-Le Marinel in die Kongo, Aswan in Egipte, die voorgestelde Volta-skema in Ghana en die Oranjerivierskema; olie uit Egipte, Libië, Algerië, Angola en Nigerië.

Vanuit 'n vervoeroogpunt is die belangrikste mynboubedrywighede in Suid-Afrika, Rhodesië, Zambië, Liberië, Marokko, Kongo en Ghana. Die belangrikste produksie is chroom, koper, yster en mangaan.

Uit die voorgaande bespreking van ekonomiese aktiwiteit en beskikbaarheid van grondstowwe en krag is dit duidelik dat 
gebiede waar daar ' $n$ vraag na vervoer bestaan ver van mekaar geleë is, wat dus spoorverbindings bemoeilik en beperk.

Die laaste bepalende faktor is die terrein waaroor vervoer moet word. Die terrein is belangrik daar spoorweë tegnies aan die land gebonde is. Afrika het 'n smal kusgebied met min laaglande en neem die vorm van 'n omgekeerde piering aan. Die eskarp bied baie tegniese probleme vir spoorwegaanleg. Groot dele van die vasteland bestaan uit woestyngebiede terwyl die reënwoude in die ekwatoriale gebiede ook spoorwegaanleg beperk.

Dit is dus duidelik dat die geografiese, demografiese en ekonomiese toestande in Afrika nie bevorderlik is vir die aanlê van spoorlyne nie. In hierdie verband is Suid-Afrika 'n uitsondering.

Die Suid-Afrikaanse Spoorweë en Hawens, waaroor hierdie seminaar in hoofsaak handel, omsluit ' $n$ hele aantal vervoervorme, nl. spoorvervoer, padvervoer, lugvervoer, seevervoer en pyplynvervoer. Alhoewel daar in hierdie studie net aandag geskenk word aan spoorvervoer en die eindpunte van seevervoer, nl. hawens, word die rol wat vervoer in die algemeen, en meer spesifiek die Suid-Afrikaanse Spoorweë en Hawens as geheel, in die volkshuishouding van die land speel, kortliks ter inleiding geskets.

Ten einde die relatiewe belangrikheid van die land se vervoerstelsel in die volkshuishouding aan te toon, moet in die eerste plek gelet word op sy bydrae tot die totale volksinkome. In 1963-64 het die bydrae van „Vervoer" tot die volksinkome op R470 miljoen te staan gekom, d.w.s. ongeveer $8 \%$ van die totaal van R6,100 miljoen. Die S.A. Spoorweë was gedurende hierdie tydperk verantwoordelik vir ruim $87 \%$ van die bydrae van vervoer tot die volksinkome, wat aantoon dat die Spoorweë, nieteenstaande toenemende mededinging van private padvervoerders, nog steeds 'n baie belangrike en verantwoordelike taak in dié opsig het.

'n Ander faktor waarop gelet kan word is die funksie van die spoorweë as werkverskaffer. Op die grondslag van indiensnemingsyfers is die S.A. Spoorweë die grootste organisasie onder een beheerliggaam in die Republiek. Op 31 Maart 1966 was daar ongeveer 118,000 blankes en 110,000 nie-blankes in diens van die Spoorwegadministrasie. Indien Spoorwegpensioenarisse en alle afhanklikes van die bovermelde spoorwegdie- 
nare bygereken word, beteken dit dat bукаns 750,000 mense vir 'n lewensbestaan van die Suid-Afrikaanse Spoorweë afhanklik is. Die totale bedrag wat jaarliks aan sy personeel uitbetaal word in die vorm van lone en salarisse beloop meer as R250 miljoen, sodat arbeidsuitgawe verantwoordelik is vir die besteding van bykans $50 \%$ van die totale inkomste van die Administrasie.

Ook in sy funksie as verbruiker vervul die Spoorweë 'n belangrike rol in die landsekonomie. Die Spoorweë is ook die grootste enkele verbruiker in die Republiek en dien op dié wyse as afsetgebied vir die produkte van alle sektore van die landsekonomie. In 1910 het die totale spoorwegaankope ongeveer R7 miljoen bedra, terwyl dit in 1964/1965 die enorme bedrag van R200 miljoen beloop het, waarvan slegs $\mathrm{R} 11$ miljoen in die buiteland bestee is. In 1910 het regstreekse invoere uit die buiteland bykans $60 \%$ van die totale aankope gevorm, terwyl dit in 1964-65 gedaal het na ongeveer 5\%. As gevolg van die vraag wat die Spoorweë skep, hetsy in die vorm van verbruiksgoedere of kapitaalgoedere, het 'n belangrike mark vir private nywerhede in die land ontstaan. Trouens, daar is vandag etlike sleutelnywerhede in ons land wat vir hulle bestaan feitlik geheel en al afhanklik is van die mark wat die Spoorweë skep.

'n Minder bekende funksie van die S.A. Spoorweë is dié van kapitaalvoorsiening. Die balanse wat die Spoorweë in sy verskeie fondse hou, bv. die Superannuasiefonds, Vernuwingsfonds, Tariewereserwefonds, en andere, word by die Staatskuldkommissie belê wat weer die geld in die vorm van lenings aan Staatsondernemings voorskiet. Die totale bedrag van al hierdie fondse beloop tans ongeveer R600 miljoen.

As gevolg van die wesenlike verskil tussen spoorweë en hawens word elk afsonderlik in 'n afdeling behandel. Daar moet egter op gewys word dat gegewens in verband met spoorweë en hawens in ander lande van Afrika baie beperk, verouderd en ook onbetroubaar is.

\section{AFDELING I. SPOORVERVOER}

\section{BEHEER OOR SPOORWEGSTELSELS}

Die vernaamste doelstelling van 'n spoorwegadministrasie 
is om toe te sien dat 'n doeltreffende en toereikende vervoerstelsel ter bevordering en ontwikkeling van die land verskaf word.

Om hierdie doelstelling te bereik moet daar doeltreffende beheer uitgeoefen word. Daar is drie vorme van beheer, nl. staats-, semi-staats- of privaat.

Die Rhodesiese Spoorweë is ook 'n staatsonderneming en voor die onafhanklikheidsverklaring van Noord-Rhodesië, tans Zambië, het die regerings van Suid-Rhodesië en Noord-Rhodesië gesamentlik die spoorweë besit en is dit deur 'n spoorwegraad soortgelyk aan dié van die Oos-Afrikaanse Spoorweë, beheer. Na die ontbinding van die Federasie is die besittingsreg en finansiële verantwoordelikheid van die Rhodesiese Spoorweë oorgedra aan die regerings van Noord- en SuidRhodesië terwyl 'n spoorwegraad bestaande uit 3 verteenwoordigers vanuit Rhodesië en Zambië met 'n onafhanklike voorsitter nog verantwoordelik vir kontrole is.

Die Spoorweë in Malawi word sedert Oktober 1964 privaat beheer en geadministreer onder die naam „Malawi Railway Limited". 'n Bykomende spoorwegmaatskappy, die "Central Africa Railway Company Limited" wat 'n tak van die Malawi Spoorweë is sowel as 'n bykomende spoorwegonderneming, die "Trans-Zambesi Railway Company Limited" wat 'n vennoot van die Malawi Spoorweë is, hanteer tesame met eersgenoemde maatskappye, alle verkeer wat aangebied word.

Die beheer van die Swazilandse Spoorweë word uitgeoefen deur 'n Raad waarvan die voorsitter ook die hoof-beheervoerende amptenaar is. 'n Ooreenkoms is aangegaan tussen die Swazilandse Spoorweë en die Spoorwegadministrasie van Mosambiek waaronder lg. vir die beheer en werking van die lyn verantwoordelik is.

Die Oos-Afrikaanse Spoorweë is saamgestel uit die vorige Kenia, Oeganda- en Tanganjika-spoorweë en alhoewel elkeen van hierdie gebiede 'n eie regering het, val die bestuur van die spoorweë onder een liggaam wat bekend staan as die "East African High Commission".

Die Egiptiese Spoorweë is ook 'n staatsonderneming, Met die re-organisasie in 1956 het 'n liggaam tot stand gekom "The Railway Authority" wat vir die bestuur verantwoordelik is.

In Ghana word die spoorweë ook van staatskant georga- 
niseer en finansier. Die Ghanese spoorweë is dus ook staatseiendom en beheer daarvan berus by die hoofbestuurder van die spoorweë en die hawens van Ghana.

Die meeste spoorwegstelsels in Afrika word dus deur die staat beheer. Die rede waarom die Suid-Afrikaanse Spoorweë en Hawens deur die staat beheer word hang ten nouste saam met die historiese ontwikkeling van spoorweë in die land. Die eerste spoorlyn in Suid-Afrika wat op 26 Junie $1860 \mathrm{amp}-$ telik vir verkeer tussen Point en Durban oopgestel is, is deur die „Natal Railway Company” gebou en bestuur. Daarna het twee maatskappye in die Kaapkolonie, nl. die "Cape Town Railway and Dock Company" en die „Wynberg Railway Company" begin met die bou van 'n spoorlyn tussen Kaapstad en Wellington asook tussen Kaapstad en Wynberg.

$\mathrm{Na}$ die ontdekking van diamante by Kimberley in 1870 het die Kaapse Regering die private maatskappye in 1873 onteien en is die "Cape Government Railways" later gestig. Weens die dringende noodsaaklikheid vir spoorlyne van die hawens na die binneland om die nodige materiaal en voedsel na die diamantvelde te vervoer en as gevolg van 'n gebrek aan kapitaal by die private maatskappye het die Regering besluit om die Spoorweë self oor te neem.

In 1877 is die "Natal Government Railways" gestig en het die spoorweë ook in Natal 'n staatsinstelling geword. Die regerings van die Transvaal en die Oranje-Vrystaat het die belangrikheid van 'n spoorwegverbinding met die buitewereld besef, maar die twee republieke was arm en die bevolkings klein. Na die ontdekking van goud in 1886 aan die Witwatersrand het die ekonomiese posisie van Transvaal baie verbeter en kon daar begin word met die bou van spoorlyne.

Gedurende die Tweede Vryheidsoorlog (1899-1902) is die spoorweë van die twee Republieke onder beheer van die "Imperial Military Railways" geplaas en nadat vrede gesluit is, het hierdie spoorweë as die "Central South African Railways" (C.S.A.R.) bekend gestaan.

Die "Central South African Railways", die "Cape Government Railways" en die "Natal Government Railways" het met Uniewording saamgesmelt in die Suid-Afrikaanse Spoorweë en Hawens onder die beheer van 'n Staatsminister en met 'n Hoofbestuurder as hoofuitvoerende beampte.

In 'n jong land soos Suid-Afrika is spoorweë nodig vir die 
ontwikkeling van uitgestrekte en dunbevolkte gebiede, nog voordat die lyne, uit 'n handelsoogpunt beskou, betalend is. Private maatskappye is begryplikerwys huiwerig om die bou van lyne aan te durf en sou hulle dit ook doen, word hulle deur die moontlikheid van mededinging afgeskrik. Onder hierdie omstandighede was dit dus onvermydelik dat die regering self die verantwoordelikheid vir die bou en bestuur van die spoorweë aanvaar het.

Deurdat die spoorwegorganisasie 'n staatsinstelling is, is dit moontlik om tariewe aan te pas by die beleid van nasionale ontwikkeling. Die staat is verder in 'n groter mate in staat om spoorweë te finansier vanweë die feit dat lenings maklik en gewoonlik teen laer rentekoerse verkry kan word.

In die geval van die S.A. Spoorweë mag daar volgens wet nie doelbewus vir groot winste beplan word nie.

\section{ORGANISASIE VAN SPOORWEE}

Voordat die organisasie van die Suid-Afrikaanse Spoorwee in detail behandel word, word daar net kortliks gelet op die organisasie van sommige van die ander spoorweë in Afrika.

Die bestuur van die Rhodesiese Spoorweë na die ontbinding van die Federasie, maar voor die onafhanklikheidsverklaring van Zambië, het bestaan uit 'n hoofbestuurder, drie afdelingsbestuurders en drie distriksbestuurders. Die afdelings- en distriksbestuurders is saam verantwoordelik aan die hoofbestuurder.

In die geval van die Malawiese Spoorweë is 'n raad van direkteure met 'n voorsitter en besturende direkteur aan die spits. Een hoofbestuurder voer die gesag oor al drie maatskappye onderhewig aan die beheer van 'n direksie.

Die Oos-Afrikaanse Spoorweë is ook gebaseer op 'n de. partementele stelsel.

Die direksie vn die Egiptiese Spoorweë is saamgestel uit tien politieke lede, drie ministers en die Direkteur-generaal van Spoorweë. Departementskantore is in vier gebiede opgerig met 'n eie hoofbestuurder vir elke gebied en almal onderworpe aan die gesag van die Direkteur-generaal.

Die organisasie van die Ghanese Spoorweë is baie soortgelyk aan die van die Suid-Afrikaanse Spoorweë. 
In verband met Suid-Afrika bevat Artikel 2(1) van Wet nr. 17 van 1919 'n bepaling dat die spoorweë en hawens van die Unie geadministreer en geëksploiteer word onder beheer en gesag van die Goewerneur-generaal-in-Rade (tans die Staatspresident), wat uitgeoefen word deur 'n staatsminister wat deur die Spoorwegraad geadviseer word. Die Raad bestaan uit 'n staatsminister as voorsitter, en hoogstens drie kommissarisse wat deur die Goewerneur-generaal-in-Rade aangestel word.

Die bestuur en die eksploitasie van die spoorweë en hawens word, met inagneming van die beheer van die minister, uitgeoefen deur die hoofbestuurder, wat gelei word deur sodanige regulasies as wat die minister van tyd tot tyd in oorleg met die raad voorskryf. Die hoofbestuurder word bygestaan deur twee adjunk-hoofbestuurders en vyf assistent-hoofbestuurders aan die hoof van die volgende departemente:

(a) Lugdiens

(b) Handel

(c) Bedryf en padvervoer

(d) Personeel

(e) Tegnies

asook 'n finansiële bestuurder, en 'n hoof, beplanning en produktiwiteit. Bostaande vorm die bestuur van die spoorweë. Verder is die Suid-Afrikaanse Spoorweë geografies in nege afdelings ingedeel, wat elk onder beheer van 'n afdelingsbestuurder staan.

\section{PERSONEEL VAN SPOORWEE}

\section{Personeelomvang:}

In bylae A word besonderhede van die personeelsterktes van enkele Spoorweë in Afrika, spoorwydtes, spoorlengtes en tonmyle verstrek. Volgens hierdie staat het die Suid-Afrikaanse spoorweë meer as vyf maal soveel personeellede in diens as die spoorweg met die volgende meeste personeellede, nl. die Oos-Afrikaanse spoorweë. In bylae B word die personeelsterkte in verband gebring met die spoorlengte en in bylae $\mathrm{C}$ met die tonmyl vervoer van elke spoorweg. As gevolg van verskil in bedryfsmetodes, in tipe van spoorwegnetwerk, omvang van dienste en moeilikhede om juiste inligting te bekom is hierdie 
syfers nie vergelykbaar nie, en word slegs interessantheidshalwe gekwoteer.

In bylae $\mathrm{D}$ word die totale personeelsterkte van die SuidAfrikaanse Spoorweë aangetoon. Dit is opmerklik dat die aantal personeellede veral sedert 1956-57 nie aanmerklik gestyg het nie. In teenstelling met hierdie matige toename in die aantal personeellede het die tonmyle en passasiersmyle wat per spoor verskuif is aanmerklik toegeneem. Die gevolg is dus dat meer werk gedoen is mel relatief minder personeellede met die gevolg dat arbeidsproduktiwiteit gestyg het. Bylae $\mathbf{E}$ is ' $\mathrm{n}$ berekening van die toename in arbeidsproduktiwiteit sedert 1950-51. Volgens hierdie gegewens het die indeks van arbeidsproduktiwiteit toegeneem van 1,000 in 1950/51 tot 1253 gedurende 1964/65 met ander woorde, met 25.3\%. Dit beteken dat arbeidsproduktiwiteit op die spoorweë met ongeveer $1.5 \%$ per jaar toegeneem het gedurende hierdie periode.

\section{Personeelverhoudings:}

Die personeelverteenwoordiging op die spoorweë het geleidelik ontwikkel. Die huidige stelsel is gegrond op die beginsel wat omskryf word as ,identiteit van belange", waarvolgens die personeel in sewe groepe verdeel is volgens die aard van die tipe werk wat deur die lede verrig word, klerklike grade, lokomotiefdrywers, ens. Lidmaatskap tot die personeelvereniging is heeltemal opsioneel.

Die sewe personeelverenigings is as vakverenigings geregistreer ooreenkomstig die bepalings van die Nywerheidsversoeningswet en word erken as die enigste organisasie wat gemagtig is om vertoë te rig oor die diensvoorwaardes van sy besondere groep en beleidsake word net met die verteenwoordigers van die betrokke personeelvereniging bespreek.

Ook word Kleurling- en Indiërdienare toegelaat om hul eie personeelverenigings te stig wat deur die administrasie erken word. Bantoepersoneelverteenwoordiging is gegrond op die bepalings van die Wet op Naturellearbeid (Wet nr. 48 van 1953).

\section{Pensioenfonds:}

Elke gereelde dienaar is verplig om lid van die Nuwe 
Spoorweg- en Hawesuperannuasiefonds te word en moet solank hy in diens bly ' $n$ persentasie van sy pensioendraende besoldiging bydra na gelang van ouderdom op die datum waarop bydraes begin. Die administrasie dra 'n gelyke persentasie by.

Die Spoorwegsiekefonds, wat deur ledegelde en bydraes van die administrasie ondersteun word, voorsien deur sy spoorwegdokters geneeskundige en hospitaalbehandeling asook medisyne aan lede en hul gesinne selfs nadat hulle met pensioen uit diens getree het. Nie-blanke dienare is ook lede van die fonds.

\section{Opleiding van personeel:}

Voor 1938 het opleiding van spoorwegpersoneel sporadies en meestal op eie inisiatief plaasgevind maar as gevolg van 'n ondersoek wat in daardie jaar ingestel is, is die spoorwegkollege te Esselenpark opgerig teen 'n totale koste van R5,300,000.

Behalwe hierdie opleidingsinrigting is daar ook opleidingsfasiliteite vir sekere groepe personeel soos rangeerders op die verskillende afdelings.

Tans vind ons aan die kollege 60 instrukteurs terwyl die totale getal studente wat jaarliks opgelei word op 3,600 te staan kom. Die instrukteurs is almal spesiaal gekeurde amptenare wat aan die kollege opgelei is in die metodiek van onderrig. Op die afdelings word 'n verdere 7,100 jaarliks opgelei.

\section{Beursskemas:}

Die administrasie beskik ook oor 'n beursskema vir ingenieurs en ander tegniese personeel asook 'n B.Comm.beursskema vir voltydse studie aan 'n residensiële universiteit in Suid-Afrika. Verder bestaan daar ook 'n beursskema vir deeltydse studente.

Die volgende beurse is tot 31 Maart 1965 toegeken:

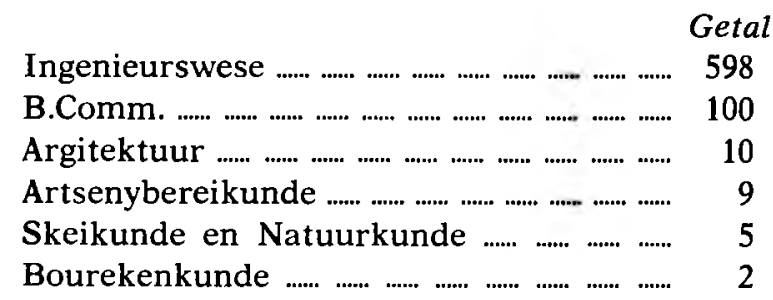




\section{Personeelkeuring en -werwing:}

Op arbeidsgebied speel personeelkeuring 'n baie vername rol in 'n poging tot verhoogde produktiwiteit. Dit moet steeds die oogmerk van 'n onderneming wees om die regte man op die regte werk te hê want dit bring arbeidsvreugde en verhoog die werker se produksievermoë.

Waar daar egter volle indiensneming is soos in SuidAfrika tans die geval is, is personeelkeuring, wat impliseer dat die persoon wat nie geskik bevind word nie, weggewys word, net nie moontlik nie. Elke beskikbare werker moet gebruik word. Die Suid-Afrikaanse Spoorweë oorkom die probleem tot ' $n$ groot mate deur van 'n klassifikasiestelsel gebruik te maak. Volgens hierdie stelsel word elke applikant wat in diens geneem word se vermoë wetenskaplik bepaal en dan op werk geplaas wat hy behoort te kan behartig. Op hierdie wyse word die beste gebruik gemaak van die beskikbare mensemateriaal en word die arbeidstekort tot 'n mate verlig.

\section{Meganisasio:}

As gevolg van die snelle ontwikkeling op die gebied van gemeganiseerde kantoortoerusting is 'n sentrale afdeling vir kantoormeganisasie vroeg in 1957 gestig wat hoofsaaklik te doen het met die beheer oor en koördinering van gemeganiseerde toerusting en prosedures.

Die beheer oor kantoormeganisasie word deur 'n komitee, genoem die Bestuurskomitee insake Kubernetika, uitgeoefen. Hierdie komitee word deur 'n Tegniese Onderkomitee bygestaan wat hom van advies oor tegniese probleme bedien.

Die spoorwegadministrasie het tans tien moderne rekenoutomate in gebruik en die standardisering van prosedures op al die nege geografiese afdelings is reeds verwesenlik.

Die spoorweë het sy eie kursus in Organisasie en Metodes ontwerp en dit word aan die spoorwegkollege te Esselenpark aangebied. Die doel met die opleiding is om die betrokke amptenare in staat te stel om die tegnieke sowel in die loop van hulle dagtaak as gedurende spesiale of voltydse ondersoekwerk toe te pas ten einde doeltreffendheid te verhoog deur of 'n beter diens te lewer of die koste daarvan te verminder of albei. 


\section{SAMEWERKING TUSSEN SPOORWEE IN AFRIKA}

Reeds in 1949/50 het die gedagte ontstaan om samewerking te bewerkstellig tussen spoorwegadministrasies veral in Suidelike Afrika.

Suid-Afrika het in 1950 die inisiatief op hom geneem en 'n konferensie belê om 'n permanente organisasie daar te probeer stel ten einde die ontwikkeling van die vervoerwese van die suidelike gedeelte van Afrika te bevorder en te koördineer. Hierdie konferensie het egter misluk aangesien die ander spoorweë van mening was dat Suid-Afrika die organisasie wou oorheers.

$\mathrm{Na}$ afsonderlike samesprekings met die hoofbestuurders van die spoorweë in Mosambiek, Rhodesië en Oos-Afrika in 1953 het mnr. D. H. C. du Plessis, destydse hoofbestuurder van die Suid-Afrikaanse Spoorweë, daarin geslaag om die samewerking van genoemde administrasies te kry vir die hou van periodieke konferensies op bestuursvlak ten einde gemeenskaplike probleme te bespreek en onderlinge samewerking in die oplossing daarvan te weeg te bring. Die eerste konferensie is gedurende Oktober 1954 in Johannesburg gehou met die volgende administrasies verteenwoordig:

B.C.K. en C.F.L. (Belgiese Kongo);

C.F.B. (Angola);

C.F.M. (Mosambiek);

E.A.R. en H. (Oos-Afrika);

N.R. en T.Z.R. (Njassaland);

R.R. (Rhodesië); en

S.A.S. en H. (Suid-Afrika).

Hierdie konferensie was baie geslaagd en op 'n later stadium het OTRACO (met hoofkwartier in Leopoldstad) en C.F.L. (oud-Belgiese Kongo) ook tot die konferensie toegetree. Verdere konferensies is gehou gedurende:

November 1955 in Nairobi;

Junie 1957 by Victoria-waterval;

Junie 1959 in Lourenco Marques;

Mei 1960 in Johannesburg en die volgende konferensie sou in Elizabethville in 1962 gehou word.

Die spourwegorganisasies wat deur hierdie konferensies 
aaneengeskakel is word in bylae $F$ aangetoon. Die voordele wat hierdie konferensies opgelewer het was o.a. hegter samewerking tussen die verskillende administrasies, onderlinge uitruiling van duur navorsingsuitrusting, die uitvoer van proefnemings in verband met verskillende aspekte van spoorwegbedryf op 'n gesamentlike grondslag en die deelname deur meer as een administrasie aan oorsese sendings; dit het ook gedien as forum vir die wisseling van idees en inligting. Die kleiner administrasies het meer voordeel uit hierdie konferensies getrek. Dit het egter groot voordele vir die Suid-Afrikaanse nywerhede wat spoorweguitrusting vervaardig, ingehou want die ander administrasies het die Suid-Afrikaanse patroon van ontwikkeling gevolg en Suid-Afrikaanse materiaal gebruik.

Die konferensie van 1962 in Elizabethville is egter afgelas as gevolg van politieke onrus in die Kongo en die onttrekking van die E.A.R. en H. in Januarie 1962 en as gevolg van die verdere politieke „winde van verandering" het hierdie mooi organisasie doodgeloop.

Samewerking is tans hoofsaaklik beperk tot die spoorweë van die aangrensende gebiede.

\section{VERVOER VAN GOEDERE EN PASSASIERS}

\section{Omvang van goedereverkeer:}

Die volume van goedereverkeer wat jaarliks deur spoorweë in Afrika gehanteer word, word in bylae $\mathrm{G}$ aangetoon. Hiervolgens is dit duidelik dat die grootste hoeveelheid goedereverkeer in Afrika deur die Suid-Afrikaanse Spoorweë vervoer word. Mosambiek het die tweede grootste aandeel in die hoeveelheid goedere vervoer, maar daar moet ook in ag geneem word dat die grootste gedeelte van dié verkeer na bestemmings in Rhodesië en op die Witwatersrand vervoer word. Die tonnemate wat deur die lande van Noord-en Midde-Afrika vervoer word, is betreklik min en bestaan meestal uit grondstowwe en half vervaardigde goedere.

Daar is verskeie metodes wat gebruik kan word om 'n vergelyking tussen die goedereverkeer van verskillende lande te tref. In bylae $\mathrm{H}$ word die tonmyl in verhouding tot die bevolking aangedui. Ons sien weer eens dat die S.A. spoorweë die gunstigste posisie inneem en uit die kaart blyk dit dat die 
meeste ander Afrikalande minder as 100 tonmyl per capita van die bevolking vervoer.

Deur die aantal tonmyl met die roetemylafstand te deel word 'n aanduiding verkry van die mate waartoe spoorweë die beskikbare spoorlyne benut. Soos gesien kan word in bylae I word die spoorwegnetwerk in Suid-Afrika meer benut as in enige ander land in Afrika.

\section{Aard van goedereverkeer in Suid-Afrika:}

Goedereverkeer van die S.A. Spoorweë kan volgens die tariewe wat betaalbaar is verdeel word in sg. hoëtariefverkeer en laetariefverkeer. Die meeste goedere wat deur die S.A.S. vervoer word, ressorteer onder die laetariefklasse. Dit verteenwoordig ongeveer $84 \%$ van die totale tonnemaat goedere wat vervoer word, maar lewer as gevolg van die lae peil van tariewe slegs $50 \%$ van die totale goedere-inkomste.

Hoëtariefverkeer, aan die anderkant verteenwoordig slegs $16 \%$ van die totale hoeveelheid verkeer maar lewer amper $50 \%$ van die totale inkomste. Die rede vir hierdie verskynsel is dat die vervoertarief baie hoog in verhouding tot die gewig van die artikels is. Die waarde van die kommoditeite is egter so hoog dat die vervoertarief 'n baie klein gedeelte van die kosprys uitmaak.

Die laetariefverkeer toon 'n steeds stygende neiging. Landbouprodukte word in toenemende hoeveelhede vervoer en steenkool- en ertsverkeer beslaan 'n groot gedeelte van die totale tonnemaat laetariefverkeer wat vervoer is. Padvervoerders stel min belang in die vervoer van massaprodukte wat in die laetariefgroepe val maar wel in daardie wat in die hoër tariefklasse val. Met die uitsondering van steenkool wat van die Witbank-omgewing na die Randse gebied deur padvoertuie vervoer word, kan daar aanvaar word dat die Spoorweë sy regmatige gedeelte van laetariefverkeer behou en uitbrei.

Die gemiddelde vervoerafstand vir alle inkomstedraende verkeer het van $263 \mathrm{myl}$ in 1955/56 tot 314 myl in 1965/66 gestyg wat ' $n$ aanduiding is dat die Spoorweë 'n steeds groeiende gedeelte van die langafstandverkeer bykry terwyl 'n gedeelte van die kortafstandverkeer aan die padvervoerders afgestaan word.

Die gevolg van die voorgaande is dat laetariefverkeer, wat 
meestal onlonende verkeer is, redelik vinnig vermeerder terwyl hoëgraadse verkeer aan die anderkant minder snel vermeerder. Die gemiddelde inkomste per tonmyl verkeer wat vervoer word neem dus nie net as gevolg van die verlenging in gemiddelde vervoerafstand af nie maar ook as gevolg van hierdie verskuiwing in die samestelling van die verkeer ten gunste van laetariefverkeer. In die huidige tydsvak van stygende pryse, wat vervoerkoste laat styg, skep hierdie verminderde inkomste per tonmyl ernstige probleme vir die S.A. Spoorweë.

\section{Volume van passasiersverkeer:}

Daar sal bemerk word dat Egipte en Suid-Afrika tesame ongeveer $86 \%$ van die totale passasiersverkeer in Afrika behartig. Dit is opmerklik dat beide hierdie lande voorstedelikepassasiersdienste verskaf - 'n verskynsel wat in geeneen van die ander lande aangetref word nie.

Vervolgens word 'n kort beskrywing van die passasiersverkeer in enkele Afrikalande gegee.

Egipte: Die grootste gedeelte van die bevolking is langs die Nylrivier en in die omgewing van die twee grootste stede, Kaïro en Alexandrië woonagtig en die omstandighede is dus uiters geskik vir die vervoer van kortafstandpassasiers. Die aantal passasiers wat in 1958 vervoer is, het op 88,675,000 te staan gekom en die nuwe besproeiingskemas wat op die bou van die Aswandam gevolg het, was verantwoordelik dat die passasiersverkeer tot nagenoeg $108,180,000$ in 1964 toegeneem het.

Algerië: In Algerië het die aantal passasiersreise 'n dalende neiging oor die afgelope paar jaar getoon. In 1962 is 5,830,900 passasiers in die land vervoer. Die jongste gegewens toon egter dat die aantal tot 2,045,000 in 1964 gedaal het. Gedurende 1965 het die aantal reise egter na beraming weer tot 2,574,000 gestyg. Algerië is 'n goeie voorbeeld van hoe politieke krisisse die passasiersverkeer van 'n land kan beïnvloed.

Oos-Afrika: In 1962 het die aantal passasiers wat vervoer is op 5,532,000 te staan gekom, maar hierdie getal is besig om te daal en die huidige syfers sal heelwat laer wees. Onbeperkte padmededinging is die oorsaak van die vermindering 
in die aantal passasiers.

Ghana: In Ghana het die aantal treinpassasiers redelik konstant gedurende die afgelope paar jaar gebly en word daar tans ' $n$ geringe toename ondervind. In 1964 is omtrent $5,700,000$ passasiers vervoer vergeleke met 5,532,000 in 1962.

Marokko: Marokko toon dieselfde neiging as die ander Afrikalande sover dit passasiersverkeer betref. In 1962 het passasiersreise op 3,847,400 te staan gekom wat 'n daling van $20 \%$ vergeleke met die vorige jaar se syfer is. In 1963 het die syfer tot 3,919,606 gestyg en vir 1964 het dit op 4,020,000 te staan gekom.

Nigerië: Omtrent 8 miljoen passasiers is in 1964 vervoer vergeleke met 7,015,000 in 1962.

Rhodesië: As gevolg van die ekonomiese vooruitgang toon die passasiersreise 'n steeds toenemende groeikoers. Nie-blanke reisigers neem veral snel toe en die passasiersvervoer beloop bykans vyf miljoen. Daar kan verwag word dat hierdie syfer aansienlik sal toeneem solank oliesanksies teen Rhodesië toegepas word en meer blankes verplig sal word om van openbare vervoerstelsels gebruik te maak. Die vervoerstelsels van Rhodesië sluit aan by dié van die Republiek, Zambië en Mosambiek.

Tunisië: In 1963 is $12,216,000$ passasiers in Tunisië vervoer waarvan die meeste $(11,700,000)$ oor staatsbeheerde spoorlyne in die omgewing van Tunis vervoer is.

S.A. Spoorweë: Die grootste gedeelte van die passasiersverkeer in Suid-Afrika is beperk tot die voorstedelikegebiede waar $94 \%$ van die totale aantal vervoer word. Van die $400,000,000$ passasiers wat met die voorstedelike dienste in $1964 / 65$ vervoer is, is $279,000,000$ derdeklas (nie-blankes) en die oorblywende gedeelte $(121,000,000)$ meestal blankes. Die jaarlikse toename in eerste- en tweedeklasvoorstedelikereise is $3.8 \%$ terwyl dit $13.67 \%$ in die geval van derdeklasvoorstedelike reise beloop.

Met die verbetering van ons paaie het hooflynpassasiersreise baie afgeneem sover dit eerste- en tweedeklasreise betref, $\mathrm{nl}$. van nagenoeg 17 miljoen in 1946/47 tot slegs 5 miljoen in $1965 / 66$. Derdeklashooflynreise is nog steeds besig om teen 'n 
jaarlikse groeikoers van ongeveer $3 \%$ toe te neem.

Oor die afgelope dertig jaar het 'n grootskaalse verskuiwing van die bevolking van die platteland na die stede plaasgevind. Die jaarlikse groeikoers van die blankes in die stedelike gebiede het in 1960 op $3.7 \%$ te staan gekom vergeleke met die jaarlikse groeikoers van $3.8 \%$ in die uitreiking van voorstedelike seisoenkaartjies. Die nie-blanke stedelike bevolking toon 'n jaarlikse toename van $6.86 \%$ terwyl seisoenkaartjieuitreikings teen $13.7 \%$ jaarliks toeneem. 'n Meewerkende faktor tot hierdie groot vermeerdering in nie-blanke reise is die hervestigingsbeleid van die regering. Gedurende die afgelope aantal jare het die spoorweë 'n hele reeks spoorlyne gebou wat die hervestigingsgebiede regstreeks met die stede verbind het. Alhoewel hierdie lyne deur die regering gewaarborg word en verliese deur die tesourie aan die spoorweë vergoed word, het die bou van hierdie lyne baie kapitaalbesteding van die spoorweë geverg. Na raming is die totale kapitaalbesteding op hierdie lyne byna R100 miljoen. Gedurende die afgelope paar jaar het die plattelandse blanke bevolking jaarliks met $1.07 \%$ afgeneem terwyl die hooflynpassasiersreise ook met ongeveer $1 \%$ jaarliks afgeneem het. Dit is dus duidelik dat bevolkingsaanwas ' $n$ bepalende invloed op die passasiersverkeer van die S.A. Spoorweë het.

'n Ander faktor wat beslis ' $n$ invloed op die aantal passasiersreise gehad het, is die toename in gelisensieerde motors op ons paaie wat van 895,400 in 1960 tot $1,061,000$ in 1963 gestyg het. Die styging in die per kapita inkomste van die bevolking het meer mense in staat gestel om met vakansie te gaan en meer mense kan gevolglik ook bekostig om motors te koop en tydens vakansies per motor te reis eerder as om van spoorwegdienste gebruik te maak.

Nie-blanke reise in die stede is besig om teen ' $n$ jaarlikse groeikoers van $11 \%$ toe te neem en die verwagting is dat hierdie groeikoers redelik konstant sal bly totdat Suid-Afrika sy optimum ekonomiese groeipunt bereik het waarna die aantal voorstedelike passasiers min of meer tred sal hou met die toename in die stedelike bevolking. Eerste- en tweedeklaspassasiers (blankes) in die stede neem toe teen $2.6 \%$ per jaar.

Uit die voorafgaande is dit duidelik dat die vervoer van voorstedelikeverkeer na die nywerheidsgebiede 'n ernstige vervoerprobleem in die toekoms sal skep. In teenstelling met 
spoorvervoer word ander vorms van vervoer deur die gebrek aan voldoende padruimte en die onbeskikbaarheid van parkeergeriewe aan die begin- en eindpunte van die reise beperk. Hoewel pogings alreeds aangewend word om hierdie probleme die hoof te bied, is die huidige geriewe onvoldoende en daar ontstaan reeds verkeersopeenhopings en vertragings op die paaie van ons grootste stede. Openbare vervoer is besig om die plek van die motor in die stedelike gebiede van die Westerse lande in te neem en die grootste ontwikkeling behoort dus in hierdie sektor plaas te vind.

Sover dit die behoeftes van verafgeleë gemeenskappe betref en dienste in stedelike gebiede waar vyf haltes per myl nodig is, is die motorbus weens sy aanpasbaarheid die doeltreffendste vorm van vervoer. Die dravermoë van 'n bus is egter beperk en op die hoofroetes waar daar 'n groot verkeersaanbod is, moet daar 'n vinnige vorm van vervoer wees om die huidige motoriste tevrede te stel.

Hierdie bewerings word gestaaf deur die bevindinge van 'n onlangse ondersoek na die stedelike padvervoerprobleme van Suid-Afrika wat deur die Buro vir Ekonomiese Navorsing van die Universiteit van Stellenbosch onder leiding van prof. C. Verburgh uitgevoer is.

\section{TEGNIESE EN ONTWIKKELINGSASPEKTE VAN SPOORVERVOER}

In Afrika is daar verskillende spoorwydtes in gebruik. Die belangrikstes is die $4^{\prime} 8 \frac{1}{2}$ ", die meterstandaards en die $3^{\prime} 6^{\prime \prime}$ spoor. Verskeie lande het meer as een spoorwydte in gebruik, soos bv. Suid-Afrika, wat benewens die $3^{\prime} 6^{\prime \prime}$ ook enkele $2^{\prime}$ spoorlyne in gebruik het.

Die keuse van die spoorwydte word tot 'n mate bepaal deur die terrein waaroor die spoor gebou moet word. Vir vlaktes met min draaie en 'n redelike konstante helling is die 4' $8 \frac{1}{2}$ " spoorwydte die mees ekonomiese. Sodra daar egter bergwêreld teëgekom word, is 'n smaller spoorwydte meer ekonomies.

In bergstreke neem die konstruksiekoste van die 4' $8 \frac{1}{2}^{\prime \prime}$ wydte buite verhouding toe weens die beperking op die draaiafstand van so 'n wye spoor. Die spoorwydte noodsaak dikwels tonnels of brûe oor valleie wat nie nodig is by 'n smaller 
spoorwydte nie. In Afrika waar die binneland met die kus verbind is moet die platorand oorgesteek word met die gevolg dat die 3' 6" spoor die mees algemeenste in Afrika is. Die spoor kan skerper draai as die 4' $8 \frac{1}{2}$ " en nogtans 'n redelike vrag dra.

In Suid-Afrika het die eerste lyn tussen Kaapstad en Wellington 'n spoorwydte van 4 ' $8 \frac{1}{2}$ " gehad. $\mathrm{Na}$ die ontdekking van diamante by Kimberley is besluit om die spoor te verleng na die diamantvelde. Aangesien dit meer ekonomies was om 'n 3' 6" spoor oor die berge te lê is daar besluit om die hele spoor op 3' 6" standaard te bou. Gelyktydig hiermee is die Natalse spoor aangepak en ook op 3' 6"-wydte. Aan die Rand het die twee lyne ontmoet en die basis gevorm vir latere ontwikkeling en uitbreidings. Alhoewel die grootste deel van die Suid-Afrikaanse netwerk op die plato geleë is wat geskik is vir die 4' $8 \frac{1}{2}$ " wydte, is die standaardwydte $3^{\prime} 6^{\prime \prime}$. Die rede kan direk toegeskryf word aan die feit dat beide spoorlyne Rand toe aan die kus begin het en feitlik dadelik oor berge moes gaan. Dit is moontlik dat indien die netwerk aan die Rand begin het en dan kus toe beweeg het, ons 'n 4' $8 \frac{1}{2}$ " spoor sou gehad het.

Die spoorweë van Rhodesië, Zambië, Katanga, Mosambiek en Angola het almal die $3^{\prime} 6^{\prime \prime}$ as standaard omdat hulle feitlik ' $n$ verlenging van die Suid-Afrikaanse stelsel is. Waar 'n nuwe spoorstelsel moet aansluit by 'n bestaande stelsel, is dit baie meer ekonomies om sy spoorwydte oor te neem as die daarstelling van ' $n$ ander spoorwydte.

In Afrika is spoorverbindings hoofsaaklik deur middel van enkellyne en is dit net die S.A. Spoorweë wat dubbellyne het.

Vervolgens word kortliks op die tipe trekkrag, sinjalering en rangskikkingsterreine in Afrika en veral in Suid-Afrika gelet.

Die keuse van trekkrag word bepaal deur o.a. die volgende faktore. Die beskikbaarheid van steenkool en olie en die hoeveelheid verkeer wat verskuif moet word. Stoom is die oudste vorm van trekkrag terwyl elektriese en dieseltrekkrag eers later ontwikkel het. As gevolg van die ontwikkeling van die laasgenoemde twee, is stoom tans verouderd en word net gebruik waar die trekkrag reeds beskikbaar is. Die nadeel van stroomtrekkrag is o.a. dat dit ' $n$ baie hoë loopkoste in verhouding tot trekkrag het, die feit dat indien lokomotiewe in meervoude gebruik word die lokopersoneel ook dienooreen- 
komstig toeneem en die tyd wat verlore gaan deur so dikwels onderweg water in te neem. Met diesel- en elektriese trekkrag is dit dus moontlik om groter vragte te verskuif sonder vermeerdering van bemanning.

In Suid-Afrika word daar as gevolg van die beskikbaarheid van steenkool en stoomlokomotiewe wat nog 'n lang ekonomiese lewe het, nog grootskaals van stoomtrekkrag gebruik gemaak. Algaande word hierdie trekkrag egter deur diesel- of elektriese krag vervang. Die praktyk het op die S.A. Spoorweë bewys dat dieseltrekkrag meer ekonomies is as elektriese trekkrag tot die verkeer 'n sekere peil bereik, waarna elektriese trekkrag weer meer ekonomies is. Dit word hoofsaaklik veroorsaak deur die hoë kapitaalkoste wat aangegaan moet word met elektrifikasie, nl. bobaanuitrusting ens., terwyl die eenheidsbedryfskoste van elektriese trekkrag goedkoper is as die van diesel. Tans vorm die reeds geëlektrifiseerde spoorlyne sowel as die gemagtigde skemas amper $30 \%$ van al die spoorlyne van die Suid-Afrikaanse Spoorweë. Die tonnemaat vervoer oor hierdie lyne vorm egter $50 \%$ tan die totaal.

\section{Sinjalering:}

In Suid-Afrika word daar meestal gebruik gemaak van semafoor sinjale (d.w.s. sinjale wat nie elektries bedien word nie) op die verskillende trajekte. Op enkele trajekte is daar egter gesentraliseerde verkeersbeheer (G.V.B.) ingestel waarvolgens die sinjale van ' $n$ hele trajek bv. vanaf Springfontein tot Bloemfontein vanaf een sentrale punt bv. Bloemfontein beheer kan word. Hierdie metode van sinjalering verhoog die kapasiteit van 'n trajek aansienlik. Ook is daar sommige trajekte waarop daar afstandbeheerde sinjale is, nl. waar sinjale by uitwykspore beheer word vanaf die naaste stasie. In gevalle waar die verkeer egter besonder hoog is soos aan die Rand word daar gebruik gemaak van „kleurligsinjale”; enkele lande in Afrika maak ook gebruik van G.V.B., bv. Liberië en Rhodesië.

Rangskikkingsterreine is die eindpunte van spoorlyne waar verkeer gesorteer, opgemaak en afgestuur word. In Suid-Afrika soos ook in die meeste lande van die wêreld staan spoorwegtrokke ongeveer $70 \%$ van die tyd en beweeg die oorblydende $30 \%$ van die tyd. Aangesien 'n groot deel van die staantyd van 
trokke in terreine deurgebring word is dit van belang om terreine so effektief moontlik te maak sodat trokke glad en vinnig kan beweeg Om hierdie doelstelling te bereik is daar op die Suid-Afrikaanse Spoorweë begin met die bou van gemeganiseerde terreine waar rangeerwerk baie vinniger en met minder personeel gedoen kan word.

\section{TEGNIESE ONTWIKKELING}

Tegniese spoorwegontwikkeling in Afrika moet gesien word teen die algemene agtergrond van die state in dié vasteland. Afrika het tans nagenoeg 40 onafhanklike state wat geografies gesien, baie van mekaar verskil. Die meerderheid van die state se spoorlyne loop slegs van die see af die binneland in sonder om baie vertakkings te hê sodat die netwerk betreklik klein is. Die vrag wat die spoorweë vervoer is hoofsaaklik grondstowwe en landbouprodukte sodat die werklike behoefte aan differensiasie in die dienste betreklik beperk is. Daar kan uit die aard van die saak ook nie veel verwag word van modernisering en outomatisasie in Afrika in vergelyking met ander toonaangewende lande oorsee nie.

Rhodesië: Rhodesië het nou 'n 16 jaar verbeteringsprogram begin ten bedrae van $R 44,000,000$ wat talle verbeterings op die ou stelsel te weeg sal bring. Die planne vir die toekoms sal kapasiteit in komende jare steeds oortref en alle verkeer kan dra. Daar word beoog om teen 1980 geheel en al vanaf stoom. na elektriese trekkrag oor te skakel. Verdere uitbreiding op trajekte is 'n tweede verbinding met Suid-Afrika wat beoog word om vanaf Wes Nicholson na Beitbrug te strek en om die hooflyn met die afgeleë Gazaland te verbind.

Oos-Afrikaanse Spoorweë: Gedurende 1965 het die spoorweë ' $n$ lening ten bedrae van $\pm R 27,000,000$ by die Wêreldbank aangegaan wat tot 1967 'n program van verbeterings moet finansier. Samesprekings is aangeknoop tussen die Oos-Afrikaanse Spoorweë en Zambië waarvolgens 'n kommissie van ondersoek ingestel is na die moontlikheid om 'n 1,200 myl lange spoorverbinding tussen Zambië se koperbelt en die Indiese Oseaan te bou.

Liberië: Op die gebied van outomatisasie het Liberië goeie 
vooruitgang gemaak met 2 lyne wat die hoëgraadse ystererts. neerslae in die land met die Atlantiese Oseaan verbind. Die een lyn wat 168 myl lank is, het 'n ten volle geïntegreerde sinjaal en telekommunikasiestelsel.

Soedan: Soedan het ongeveer R22,140,000 van die Wêreldbank geleen vir 'n drie jaar verbeteringsprogram wat die land vir sy spoorweë beoog.

Ethiopië: Die land se spoorweë beplan 'n 190 myl lange spoortrajek vanaf Nazareth na Della. Die lyn wat in 1968 klaar sal wees, sal $\pm R 70,000,000$ kos.

Sierra Leone: Hierdie land het 'n R18,000,000 uitbreidingsprogram waarvolgens hy beoog om die kapasiteit vir die vervoer van erts te verhoog.

Gaboen: Die regering van Gaboen beplan om 'n 336 myl spoor te bou van Belinga na die nuwe hawe by Owendo. Die lyn word beoog om die ysterertsneerslae wat in die gebied gevind word, te bedien.

Egipte: 'n Uitbreidingsprogram wat 5 jaar in beslag sal neem en in 1969 voltooi sal wees is nou begin. Die belangrikste projek wat geloods sal word, is die 180 myl spoorlyn vanaf Helwan om ysterertsneerslae by Baharia te bedien. 'n Groot probleem wat ondervind is met die projek, is die verskuiwing van sandduine in die gebied, wat tot 10 myl per jaar beweeg.

Senegal: Senegal beoog talle uitbreidings in sy tweede 4 jaar ontwikkelingsprogram. Die verbetering van rollende materiaal en van spoorbane geniet voorkeur in die program. Die verdubbeling van die lyn tussen Dakar en Thies word ook onderneem.

Mali: Mali se spoorweg, in vergelyking met die ander Afrikastate, is redelik modern. 'n Projek wat Mali in die vooruitsig stel is die verbinding met Guinee en die Ivoorkus.

Ivoorkus en Bo-Volta: Ivoorkus het sy eie spoorwegsisteem terwyl Bo-Volta oor geen spoorweë beskik nie. Om egter BoVolta ook met 'n hawe te verbind, word beplan om 'n lyn deur die Ivoorkus na Bo-Volta te bou.

Nigerië: Hierdie land is hoofsaaklik 'n landbouland en 
die vernaamste uitbreiding word dan ook gekonsentreer op die 390 myl lange verlenging van die lyn vanaf Boteni tot by Maiduguri om die streek met die hoofspoornetwerk te verbind.

Ghana: Die staat se 7 jaar ekonomiese program sluit die studie in van elektriese trekkrag afkomstig van die Volta hidroelektriese skema. Tot tyd en wyl die moontlikhede van elektriese trekkrag ten volle geëksploiteer is, word al hoe meer op diesel trekkrag gekonsentreer.

Kongo: Die land se spoorweë word hewig getref deur politieke, ekonomiese en militêre chaos wat die afgelope paar jaar heers.

Kameroen: Die spoorweë van die land het een hoofkenmerk en dit is 'n klein mylafstand en groot planne. As die idees verwesentlik word sal die landjie se spoorstelsel van $310 \mathrm{myl}$ uitgebrei word tot een wat sal strek vanaf Fort Archambault in die Republiek Tsjaad oor Banqui in die Kameroen tot in Sentraal Afrika.

Dahomé en Niger: Dahomé se hoofkenmerk van sy beoogde uitgebreide spoorwegstelsel is om sy verkeer in so 'n mate uit te brei dat 4 tot 5 treine van 1,000 ton per dag op sy verskillende trajekte vervoer sal kan word. Indien dit bereik sal kan word, sal dit 'n 5-voudige verbetering op die 1962 syfer meebring. Die uiteindelike oogmerk sal wees om die spoornetwerk tot in Niger uit te brei.

S.A. Spoorweë: Omdat Suid-Afrika ekonomies baie snel ontwikkel en die vraag na vervoer as gevolg hiervan ook baie vermeerder, moet die S.A. Spoorweë groot bedrae geld bestee om die kapasiteit van die spoorbaan sowel as trokbenutting uit te bou. Dit is egter nie net noodsaaklik om die kapasiteit van die S.A. Spoorweë te vermeerder nie maar ook om te moderniseer met die oog op die besparing van koste. In die huidige tydsvak van prysstygings kan die Spoorweë nie net tariewe tot dieselfde mate as die styging in pryse vermeerder nie maar bekamp hierdie inflasie deur hoër produktiwiteit, modernisering en outomatisasie.

Om te verseker dat kapitaaluitgawes in die mees ekonomiese volgorde aangegaan word, word die volgende prosedure gevolg. 
Voorstelle betreffende kapitaal- en verbeteringswerke word in die eerste plek deur 'n beplanningskomitee op die onderskeie afdelings ondersoek waarop senior amptenare sowel as 'n statistikus dien. Behoorlike gemotiveerde voorstelle word daarna na hoofkantoor vir ondersoek verwys vir sover dit uit ' $n$ bedryfsoogpunt geskik is, ekonomies geregverdig is ens. Indien 'n voorstel verdere aandag verg, word dit, afhangende van die verwagte koste en ander implikasies, na die Beplanningsraad verwys wat 'n Adjunkhoofbestuurder as voorsitter het. Indien die Beplanningsraad met die voorstel akkoord gaan, word dit aan 'n gesamentlike vergadering van die Raad en die Hoofbestuurder se komitee met die Hoofbestuurder as voorsitter, voorgelê waarna dit na die Minister vir finale goedkeuring verwys word. Parlementêre bewilliging word vervolgens verkry deur middel van die Begroting van Kapitaal- en Verbeteringswerke.

In verband met die ekonomiese regverdiging van kapitaaluitgawes word in bylae $L$ en $M$ twee voorbeelde van ekonomiese regverdigings weergegee. In beide gevalle, $\mathrm{nl}$. die bou van 'n nuwe spoorlyn en die verkorting van 'n bestaande roete sal die kapitaaluitgawe alleen aangegaan word indien die verkeer oor die lyn van so 'n orde is dat die gelykbreekpunt oorskry word.

Die volgende is die belangrikste uitbreidingsprogramme wat beoog word:

Om toenemende verkeer in ons land die hoof te bied, word die klem gelê op elektrifikasie. Elektrifikasie is egter nie in alle gevalle prakties nie. Op die Suidwes-Afrika-trajek was dieselering bv. die beste metode om die toenemende verkeer die hoof te bied omdat die probleem nie soseer gebrek aan spoorkapasiteit as water was nie. Stoomlokomotiewe sal vir nog 'n baie lang tyd in Suid-Afrika gebruik word. Dit geld veral in dele waar daar volop water en goedkoop steenkool beskikbaar is en waar verkeer nie swaar is nie.

Selfs met stoomtrekkrag kan voldoende kapasiteit vir groot verkeersvolume geskep word deur die spoorlyn te verdubbel. Afhangende van die kapasiteit wat op 'n trajek voorsien moet word sowel as die fisiese eienskappe van die trajek, is of elektrifikasie of verdubbeling van 'n trajek meer ekonomies. Die S.A. Spoorweë beplan om meeste van sy 
hooflyne gedurende die volgende dekade te verdubbel of te elektrifiseer.

Behalwe in S.W.A. waar dieselisasie reeds in 1959 op groot skaal ingestel is, word op ander trajekte gedeeltelik gebruik gemaak van diesels as trekkrag.

Diesel sal as trekkrag in die toekoms groter belangrikheid verkry aangesien dit die beleid van die spoorwegadministrasie is om nie meer stoomlokomotiewe aan te koop nie. Wanneer van stoom as trekkrag afgesien word, is dit gebruiklik om te dieseliseer op die minder intensiewe trajekte en om elektriese eenhede as trekkrag op die belangriker trajekte te gebruik. Oorweging word tans verleen om die trajek Port Elizabeth-De Aar te dieseliseer. Die trajek Oos-Londen-Burgersdorp is reeds gedieseliseer en op die nuwe spoorlyn tussen Kaapmuiden en Metsi sal diesels as trekkrag gebruik word.

'n Belangriker faktor wat in gedagte gehou moet word wanneer daar tot dieselisasie oorgegaan word is die beskikbaarheid en die kwesbaarheid van olievoorsiening.

Ook op die gebied van gesentraliseerde verkeersbeheer, beoog Suid-Afrika verdere verbeterings. G.V.B. bring 'n groot besparing van arbeid mee omdat daar nie meer treinbeheerpersoneel op stasies benodig is nie. Die trajekte KimberleyPostmasburg en Bloemfontein-Springfontein is reeds met G.V.B. toegerus terwyl die voorgestelde nuwe spoorlyne tussen Vryheid en Empangeni en Metsi-Kaapmuiden ook so toegerus sal word.

Tydens die besoek van die Minister van Vervoer aan die buiteland in 1965 het hy baie belang gestel in die moontlikhede van outomatisasie. Ten spyte van die groot aantal nie-blanke arbeiders in Suid-Afrika is dit duidelik dat 'n mate van outomatisasie sal moet geskied om probleme wat toenemende verkeer veroorsaak, die hoof te bied.

In Suid-Afrika word 2 ,boggelterreine" soortgelyk aan die wat in die buiteland aangetref word, gevind. Die een by Bloemfontein is die heel modernste en teoreties kan die boggelterrein 3,600 trokke per dag hanteer wat goed vergelyk met dié van groot oorsese spoorweë. ('n „Boggelterrein" is 'n gemeganiseerde rangskikkingsterrein). 


\section{HANDELSASPEKTE EN TARIEWE}

Die faktore wat die tariefbeleid van 'n vervoeronderneming kan beïnvloed is ondermeer die volgende: die beheervorm van die onderneming, die ekonomiese ontwikkelingstadium van 'n land, die tipe verkeersaanbod wat in 'n sekere land aangetref word en die mate van mededinging wat daar tussen verskillende vervoervorme bestaan.

Ons kry hoofsaaklik twee beginsels waarop die tariefbeleid van 'n vervoeronderneming gebaseer is, nl. „waarde van diens" en ",koste van diens". Dit moet egter nie so geïnterpreteer word dat $\mathrm{lg}$. die vasstelling van tariewe suiwer en alleen op koste bepleit nie, d.w.s. sonder om enigsins die aanvraagfaktore in ag te neem, of dat eg. weer alleen die waarde van die diens in ag wil neem en alle kostefaktore heeltemal wil ignoreer nie. Dit is veel eerder ' $n$ saak van beklemtoning, ' $n$ beslissing oor die rol wat elkeen van die faktore in die praktyk moet speel, want by vervoerondernemings dwarsoor die wêreld word steeds aan albei beginsels ' $n$ rol gegun in die vasstelling van tariewe.

Onder hierdie beginsels kry ons dat tariewe se onderste peil aangedui word deur die grenskoste van die onderneming vir die lewering van die spesifieke diens, welke koste neig om in die praktyk saam te val met veranderlike of regstreekse vervoerkoste. By die bepaling van die boonste grens vir die tarief kom die aanvraagfaktore in die spel, m.a.w. die waarde van die diens vir die gebruikers. In die praktyk word hierdie boonste grens beperk deur die mate van mededinging, eerstens van die kant van soortgelyke en ander vervoervorme, en tweedens tussen vervoergebruikers binne 'n bepaalde bedryfstak, en ook deur die bepaling dat totale inkomste en uitgawes moet klop, dat die welsyn van die land in ag geneem moet word, e.s.m.

As gevolg van toenemende kompetisie en ander faktore is die hedendaagse neiging beslis in die rigting van 'n kleiner mate van tariefdifferensiasie, met 'n sterker beklemtoning van die kostebeginsel, maar sonder negering van die waardebeginsel.

In Afrika is die tariefbeleid van die verskillende spoorwegondernemings ook op die reeds genoemde grondbeginsels gebaseer met afwykings om by ekonomiese toestande wat 
in die land heers aan te pas.

In Rhodesië is aanbeveel dat koste van vervoer 'n groter rol moet speel en dat inkomste van enige verkeer nie minder as die direkte koste verbonde aan die vervoer daarvan moet wees nie en dat die grootste gedeelte van bokoste versprei moet word oor totale verkeer met inagneming van wat elke tipe verkeer kan dra. Verkeer wat in trokvragte aangebied word en nie deur die spoorweë gehanteer word nie, word teen 'n laer tarief vervoer as kleiner hoeveelhede van dieselfde verkeer, en die regverdiging hiervoor is daarin geleë dat die spoorweë uitgawe bespaar.

Die tariefbeleid in Oos-Afrika is gebaseer op die beginsel van wat die verkeer kan dra. Om 'n beter benutting van trokke te verkry, is die tariewe ook meer in verband gebring met die koste van die diens. Die tariewe oor kort afstande is ook meer in verband gebring met proporsionele koste van hierdie tipe verkeer terwyl die minimum hoeveelhede per trok vir verskillende kommoditeite toegeneem het.

Malawi se tariefbeleid is daarop gebaseer om genoegsame inkomste uit gesamentlike tariewe te verkry teen huidige verkeersvolume om vervoer effektief te hou maar sonder om voorsiening te maak vir modernisering.

Die tariefbeleid van die S.A. Spoorweë het tot 'n paar dekades gelede amper uitsluitlik berus op die beginsel van wat die verkeer kan dra met ander woorde op die "waarde van diens"-beginsel. Gedurende hierdie tydperk was daar min binnelandse industrieë en die meeste van die vervaardigde produkte is ingevoer. Die meeste van die grondstowwe is aan die anderkant nie plaaslik verwerk nie maar uitgevoer. Op grond van die waarde van diens-beginsel is daar dus baie lae tariewe gehef op grondstowwe - wat natuurlik uitvoer bevorder het - terwyl die tariewe op ingevoerde vervaardigde goedere weer hoog was. In die praktyk het daar dus 'n tariefstruktuur ontstaan wat voorsiening gemaak het vir 'n geweldige groot tariefdifferensiasie tussen die hoogste en die laagste tariewe. Alhoewel tariewe in hoofsaak bepaal is op grond van die "waarde"beginsel, is vervoerkoste nie heeltemal buite rekening gelaat nie. So is goedere wat baie lig in verhouding tot volume is en wat dus 'n hoë vervoerkoste het, in hoë tariefklasse geklassifiseer.

Die nadeel van hierdie klem op die "waarde"-beginsel is 
dat die ontwikkeling van binnelandse nywerheidsproduksie nie bevorder is nie. Vertoë is derhalwe gelewer dat tariewe meer op die beginsel van koste gebaseer moet word. (Sien veral Verslag nr. 285, 1946: 'n Ontleding van Spoorwegtariefbeginsels en die Uitwerking van vervoerkoste op Nywerheidsontwikkeling in die Unie). Die spoorweë het egter in antwoord op die vertoë in die bogemelde verslag verklaar dat die meeste van die lae tariewe wel regstreekse vervoerkoste dek en dat die „koste van vervoer" beginsel wel gehandhaaf is. In 1948 word die Newton-komitee angestel om die hele angeleentheid van tariefbeginsels te ondersoek. Die verslag van hierdie komitee het dan ook o.a. aanbeveel dat tariewe meer op beginsel van koste vasgestel moet word.

In 1962 word die Schumann-komitee aangestel om verslag te lewer oor spoorwegtariefbeleid en nywerheidsvestiging. In die verslag wat gedurende 1964 verskyn het, word dit duidelik gestel dat spoorwegtariewe vasgestel moet word op grond van beide die „waarde” en „vervoerkoste"-beginsels. Die laer grens van die tarief word bepaal deur die regstreekse of veranderlike vervoerkoste terwyl die boonste grens van die tarief bepaal moet word op grond van wat die verkeer kan bekostig. Ander belangrike aanbevelings wat deur hierdie komitee gemaak is, is die volgende:

Die instelling van trokvragtariewe waar daar 'n laer tarief aan 'n versender toegeken sal word indien die verkeer in trokvraghoeveelhede afgestuur word. Die instelling van 'n hoër as normale tarief vir verkeer wat in klein besendings aangebied word. Die instelling van kontraktariewe. Al hierdie aanbevelings neig ook om tariewe in nouer verband met koste te bring.

In een van die vorige afdelings is daar aangetoon dat die verhouding van hoëtariefverkeer tot laetariefverkeer besig is om te daal en dat een van die meewerkende faktore die mededinging van private padvervoer is. Om mededinging suksesvol die hoof te bied is dit dan ook nodig dat tariewe in nouer verband met koste gebring moet word en dat die gaping tussen die hoogste en laagste tariewe vernou moet word. Indien die aanbeveling van die Schumann-komitee dat trokvragtariewe ingestel word, aanvaar word, sal dit ook die moontlikheid bied om deur middel van sê treinvragtariewe, mededinging te bowe te kom. So kan die spoorweë bv. 'n kontrak met 
steenkoolbelange sluit om 'n vasgestelde aantal treinvragte steenkool per week na sekere bestemminge te vervoer. As gevolg van die sekerheid van dié verkeer sal die spoorweë sekere bedryfsreëlings kan tref wat vervoerkoste sal laat daal en dus die moontlikheid laat om 'n laer as normale tarief te kwoteer

\section{FINANSIELE STRUKTUUR}

Net soos 'n enkele bedryf se belang in 'n volkshuishouding deur sy finansies bepaal word, so kan die belang van die verskillende spoorweë in Afrika ook gemeet word aan hulle onderskeie finansiële kragte. In bylae $\mathrm{N}$ word 'n vergelyking getref tussen die inkomste, uitgawe en bedryfsverhouding van die vernaamste spoorweë op die kontinent van Afrika gedurende 1961/62. Uit hierdie bylae is dit duidelik dat die S.A. Spoorweë uit 'n finansiële oogpunt gesien, by verre na die vernaamste spoorwegstelsel op die kontinent is.

In verband met die finansies van die S.A. Spoorweë, word daar in art. 127 van die Suid-Afrika-wet bepaal dat die Spoorweg- en Haweadministrasie se inkomsteverdienste genoegsaam moet wees om uitgawes aan bedryfskoste, verbeterings, waardeverminderings (hernuwing) en rente op kapitaal goed te maak. Hierdie inkomste word verkry deur die eksploitasie van Spoorweë, Hawens, Lugdiens en Pypleidings met hulle onderskeie vertakkings. Die inkomste wat so verkry word, word dan aangewend om al die bogenoemde uitgawes te dek. In hoofsaak is die S.A.S. en H. dus daargestel om doeltreffende vervoerfasiliteite te bied sonder enige winsbejag.

Inkomste: As gevolg van die feit dat die grootste gedeelte van die spoorweë se inkomste verkry word uit die vervoer van goedere, is spoorwegfinansies baie gevoelig vir ekonomiese fluktuasies. Met die huidige verswakking in die ekonomie het die gemiddelde inkomste per werkdag bv. gedaal van $R 1,200,000$ gedurende September 1965 tot R1,000,000 gedurende Januarie 1966.

Uitgawe: Net soos wat inkomste sterk deur ekonomiese fluktuasies in die landsekonomie beïnvloed word, word uitgawes ook sterk beïnvloed deur hierdie faktor, en wel meer vanweë sulke faktore soos prysstygings, salaris- en loonverhogings en die verhoging in algemene koste. Die styging van 
koste en pryse gedurende die afgelope paar jaar het natuurlik ook ' $n$ groot invloed op die bedryfstand van die S.A.S. en $H$. gehad. In die verband word verwys na par. 2, bl. 3 waar besonderhede van die jaarlikse aankope deur die Spoorweë verstrek word.

Die verskil tussen die werklike bedryfsinkomste en uitgawe lewer die wins of verlies. Uit hierdie wins word 'n bedrag na die Tariefreserwefonds oorgedra, of in die geval van 'n verlies word dit goedgemaak uit hierdie fonds.

Die Suid-Afrikaanse Spoorwegadministrasie lê elke jaar twee begrotings voor aan die Parlement. Eerstens word ' $n$ hersiene begroting vir die huidige jaar ingedien en daarna kom die hoofbegroting vir die volgende jaar ter tafel. Hierdie twee begrotings bestaan beide weer uit twee verskillende dele, nl.: die sg. „Witboekbegroting” wat bestaan uit die uitgawe vir die eksploitasie van Spoorweë, Hawens, Lugdiens en Pypleidings wat uit eie inkomsteverdienste gefinansier word en die kapitaal- of sg. „Bruinboek"-begroting wat voorsiening maak vir uitgawes aan nuwe kapitaalwerke en die vernuwing en verbetering van reeds bestaande bates van kapitale aard. Die fondse vir hierdie doel word hoofsaaklik van die tesourie geleen, en word nooit afgelos nie. Die spoorweë het dus nie 'n delgingsfonds nie. Rente op hierdie kapitaal word uit inkomstefondse betaal.

In verband met hierdie rente kan daar gemeld word dat die jaarlikse bedrag kumulatief vermeerder. As gevolg van die feit dat geen kapitaal afgelos word nie en die gemiddelde rentekoers op lenings jaarliks vermeerder, neem die rentelas van die spoorweë geleidelik toe. Gedurende die vroeg vyftigerjare was die toename van rente op kapitaal ongeveer $10 \%$ terwyl dit tans in die omgewing van $15 \%$ is.

Die gelde wat uit die Staatslenings sowel as ander bronne verkry is, het vir die 1965/66 begroting R145,667,000 beloop.

In vergelyking met die bg. begrote bedrag vir kapitaalen vernuwingswerke van die S.A. Spoorweë vir die boekjaar $1965 / 66$, het begrotings van kapitaaluitgawes van sekere ander spoorwegstelsels in Afrika soos volg vertoon gedurende 1966 (omgesit in Rand):

Kongo (Brazzaville) ................................................

Oos-Afrikaanse Federasie (1965-1967) R 732,142

Ethiopië $R 23,180,000$ R 648,000 
Liberië

R $1,258,731$

Rhodesië $\mathrm{R} 17,705,80 \mathrm{C}$

\section{AFDELING 2: HAWENS}

\section{BEHEER OOR HAWENS}

In Afrika word veral drie tipes van hawebeheer aangetref, nl. staats-, spoorweg- en ondernemingsbeheer. In sekere lande kom daar ook meer as een beheervorm voor soos bv. in Egipte waar hawens deur die staat sowel as deur ondernemings beheer word.

Staatsbeheer tref ons aan in Tunisië, Sierra Leone, Senegal, Marokko, Libië, Egipte ens. Spoorwegbeheer kom voor in SuidAfrika, Ghana, Soedan, Kenia en Tanganjika. Ondernemingsbeheer tref ons aan waar sekere maatskappye die hawens beheer, nl. Egipte, Liberië ens.

In ander lande van die wêreld kom nog 'n vierde tipe van hawebeheer voor, nl. munisipale beheer. Een van die grootste hawens in die wêreld, nl. Rotterdam, word deur die munisipaliteit beheer. Die meeste van die groot hawens word egter deur 'n openbare nutsmaatskappy beheer bv. die hawens van Londen en New York wat onderskeidelik deur die „Port of London Authority" en die „Port of New York Authority" beheer word.

Dit is interessant om daarop te let dat die beheer van hawens in Afrika meestal al die hawedienste omvat. Dieselfde liggaam is dus verantwoordelik vir die daarstelling van die hawe sowel as die lewering van alle bykomende dienste. In teenstelling hiermee is die neiging egter in ander lande om spesifieke dienste wat by die hawe gelewer word oor te laat aan private firmas terwyl die daarstelling van kaaie ens. weer berus by 'n munisipaliteit of nutsmaatskappy. In Rotterdam voorsien die munisipaliteit bv. net die kaaie en sorg dat die diepte van die hawe voldoende is terwyl private instansies verantwoordelik is vir kraandienste, sleepbootdienste, laai-, aflaai- en opbergingsdienste ens.

Die beheer van Suid-Afrikaanse hawens het gedurende 1847 begin toe plaaslike hawerade in die lewe geroep is om die onderskeie hawens te ontwikkel. Hierdie hawerade het onafhanklik van mekaar gefunksioneer maar is deur die 
staat beheer. Fondse wat nodig was vir haweontwikkeling is verkry van die staat terwyl surplusse op hawebedrywighede weer aan die staat oorbetaal is. Alhoewel die hawens van S.A. aan die begin deur plaaslike liggame bestuur is, was die hawebedryf egter van die begin af 'n saak vir die staat. Gedurende 1916 word die bestuur en beheer van die belangrikste hawens oorgedra aan die spoorwegadministrasie. Die vroeëre hawerade word verander in hawe-adviesrade wat bloot in adviserende hoedanigheid optree.

\section{HAWEFASILITEITE}

Afrika, met 'n kuslyn van $\pm 16,000$ myl, het sowat 82 hawens waarvan sommige goed ontwikkel is. Hierdie hawens kan skepe met 'n vaardiepte van 15 voet en meer akkommodeer. Die meeste hawens van belang in Afrika het gewoonlik ' $n$ hele aantal krane van 1 tot 10 ton en dan gewoonlik ook een of meer krane wat swaarder gewigte kan optel. Belangrike hawens het gewoonlik ook groot dryfkrane van 100 ton en meer bv. Algiers, Casablanca ens. Die meeste hawens het skeepshellings vir herstelwerk aan skepe en dan het die belangrikste hawens ook droogdokke wat gebruik word om herstelwerk aan groter skepe te doen. Wat egter nie so algemeen aangetref word nie is dryfdokke en slegs enkele hawens het 'n dryfdok, bv. Lagos, Duala, Suid-Afrika.

Wat aanlegplek betref het die meeste belangrike hawens genoegsame fasiliteite maar aangesien die meeste hawens in Afrika kunsmatig gebou moes word, is daar baie bestee om die nodige beskerming aan skepe te verskaf deur breekwaters te bou.

Suid-Afrika het hoofsaaklik vier hawens wat van belang is, nl. Kaapstad, Port Elizabeth, Oos-Londen en Durban. Die fasiliteite wat deur hierdie hawens gebied word vergelyk baie goed met dié van die groot hawens van die wêreld.

Die ingangsdiepte van die hawens wissel van 35 voet in die geval van Oos-Londen tot 42 voet in die geval van Durban. Hierdie ingangsdiepte maak dit moontlik vir die grootste skepe ter wêreld om die hawe binne te vaar. In Durban is daar bv. 'n skip gehanteer met 'n dieptegang van $41^{\prime} 3^{\prime \prime}$, wat slegs 9" minder as die ingangsdiepte is. Hierdie ingangsdiepte van Durban van $42^{\prime}$ vergelyk baie goed met die $45^{\prime}$ ingangsdiepte van die New Yorkse hawe. 
Die lengte van kaaie wissel van amper 2 myl in die geval van Oos-Londen tot $6 \frac{1}{2}$ myl in die geval van Durban. Die aantal aanlêplekke in die verskillende hawens is soos volg:

Kaapstad ...................................................................... 24

Port Elizabeth ...... ............................................................. 13

Oos-Londen .................................................................... 10

Durban ..................................... ….................................. 46

Hierdie aantal aanlêplekke is wel min in vergelyking met bv. die 548 van New York maar is baie in vergelyking met die ander hawens in Afrika.

Die meeste van die hawens in Afrika is gespesialiseerde hawens bv. Bougiehawe in Algerië wat hoofsaaklik ru-petroleum verskeep en die hawe van Monrovia in Liberië wat om trent net ystererts verskeep. Die hawens van Suid-Afrika is daarenteen almal algemene hawens wat voorsiening maak vir die hantering van alle tipes skepe en verkeer.

In verband met die hantering van gewone verkeer is die S.A. hawens goed voorsien van kaaikrane. Meeste van die krane is elektries aangedrewe 4 ton krane waarvan daar bv. 125 in die hawe van Durban is. Vir die hantering van groter gewigte is daar ' $n$ hele aantal 15 ton krane sowel as enkele baie groot krane. In Kaapstad is daar 'n dryfkraan met 'n hysvermoë van 60 ton op 'n vlug van 80 vt. terwyl daar in Durban 'n kaaikraan met 'n hysvermoë van 80 ton is. In verband met die gebruik van kaaikrane is dit interessant om te let op die neiging wat daar in die wêreld is om meer krane op skepe aan te bring en minder gebruik te maak van kaaikrane. In Suid-Afrikaanse hawens word skepe egter verbied om van hul eie krane gebruik te maak aangesien kaaikrane altyd beskikbaar is. 'n Uitsondering op hierdie verbod kom voor indien die kaaikrane wat beskikbaar is nie oor die nodige hysvermoë beskik om die verkeer af te laai nie. Dit kom veral voor indien die skip vrag vervoer in groot houers (containers). As gevolg van druk van Amerikaanse padvervoermaatskappye wat hul eie spesiale houerskepe laat bou het, neem verkeer in houers geweldig toe. 'n Noodsaaklike voorvereiste vir die gebruik van hierdie houers is 'n tweerigting verkeer wat in houers gelaai kan word tussen twee lande. Die uit- en invoer van Suid-Afrika is nog van so 'n patroon dat dit baie lank sal duur voordat houers tot 'n groot mate in S.A. hawens gehanteer moet word. Daar is dus geen noodsaak dat soos in 
sommige oorsese hawens spesiale bokkrane aangeskaf moet word om die houers te hanteer nie.

Vir die hantering en opberging van gewone verkeer is daar genoegsame loods- en opslagruimte by al die hawens. In Durban is daar bv. meer as 9 miljoen kubieke voet opslagruimte in loodse. Vir die hantering van bederfbare produkte is daar by alle hawens voorverkoelingsfasiliteite. Aangesien Kaapstad die vernaamste uitvoerhawe vir vrugte is, is die voorverkoelgeriewe aldaar ook die grootste, $\mathrm{nl}$. meer as 20,000 kubieke ton. Hierdie voorverkoelingsfasiliteite is die modernste in Afrika.

Die S.A. hawens maak baie goed voorsiening vir die massahantering van verkeer. By Durban en Kaapstad is groot graansuiers met 'n vermoë om graanprodukte teen 1,000 ton per uur te verskeep. Nog 'n meer moderne graansuier is tans in aanbou in Oos-Londen. In die hawe van Durban is ' $n$ private installasie vir die massahantering van suiker onlangs in gebruik geneem.

Vir die hantering van ertse en steenkool is daar in Durban twee private installasies en een groot departementele installasie wat die massahantering behartig. In Port Elizabeth-hawe is ' $n$ baie moderne ertslaai-installasie onlangs in gebruik geneem wat 1,500 ton erts per uur kan laai. Deur hierdie installasies is dit moontlik om skepe in 'n baie korter tyd as met konvensionele metodes te laai en is 'n geweldige voordeel vir skeepseienaars aangesien die vertragingskoste van 'n groot skip maklik $R 2,000$ per dag is.

Wat herstelfasiliteite aanbetref is ons hawens ook baie goed toegerus. Met uitsondering van die heel grootste skepe kan alle skepe in die droogdokke te Kaapstad en Durban gehanteer word. Elk van die droogdokke by hierdie hawens kan skepe van ongeveer 1,150 vt. huisves. Vir die herstel van kleiner skepe is daar ook skeepshellings en droogdokke. Veral in Durban is daar 'n hele aantal private maatskappye wat swaar skeepsherstelwerk onderneem en is dit baie uitsonderlik dat 'n skip nie in S.A. herstel kan word nie.

\section{ONTWIKKELINGSPROJEKTE}

Verskeie ontwikkelingsprojekte is tans in verskeie hawens in Afrika aan die gang. In Algerië is daar by die Annaha. 
hawe 'n projek van $\mathrm{R} 28$ miljoen om die hawe uit te bou. Alexandrië se hawe sal gedurende 1968 sy maksimum kapasiteit gebruik en gevolglik word tans aansienlike bedrae geld gespandeer om beskikbare fasiliteite uit te brei. In Ghana word die Tema-hawe wat van nuuts af opgebou is, nog steeds uitgebrei en verbeterings word nog aangebring.

Dit is die bedoeling om Tafelbaai-hawe aan die noordekant van die nuwe tenkskipaanlegplek uit te brei. Toetse word uitgevoer om die onderwaterse rotsformasies te bepaal ten einde die aard en omvang van bykomende geriewe vas te stel. Sodra hierdie formaliteite afgehandel is sal die uitbreidingskema in stadia onderneem word om in die groeiende behoeftes van die hawe te voldoen. Hierdie sal 'n baie omvangryke skema wees en sal die kapasiteit van die Tafelbaaihawe baie aansienlik verhoog.

Daar word ook reeds gewerk aan die bou van 'n nuwe hawehoof by Durban en hierdie werk sal in sy geheel gedurende 1970 voltooi wees. Dié werk maak voorsiening vir sewe bykomende aanlêplekke waarvan vier met vragloodse toegerus sal wees.

Sodra hierdie werk voltooi is sal 'n aanvang met die bou van 'n tweede hawehoof gemaak word wat na verwagting gedurende 1972/73 in sy geheel voltooi sal wees. Na voltooiing van hierdie skemas sal die kapasiteit van Durban-hawe nagenoeg $50 \%$ groter wees.

Dit is die bedoeling om met die ontwikkeling van die Richardsbaai-hawe voort te gaan sodra hawehoof nr. 2 by Durban voltooi is. Na verwagting sal geriewe vir die hanteer van skepe gedurende 1974 by Richardsbaai-hawe beskikbaar wees. Dit is die bedoeling dat Richardsbaai-hawe aanvanklik gebruik sal word vir die hantering van massavrag, bv. uitvoerertse, steenkool, mielies en suiker.

\section{VERKEER DEUR HAWENS GEHANTEER}

Volgens gegewens hanteer Durban die meeste vrag in Afrika, terwyl Kaapstad aan die anderkant die meeste skepe hanteer. 'n Ander groot hawe is Ceuta in Marokko wat jaarliks plm. 5,700 skepe hanteer teenoor die plm. 6,200 van Kaapstad. Tonnemaat-gegewens is egter nie beskikbaar vir Ceuta nie. Algiers hanteer ook sowat 5,100 skepe per jaar. 
Benewens Durban is Lourenco Marques wat die hantering van vrag betref die belangrikste in Afrika. Gegewens vir hawens in Egipte is ook nie beskikbaar nie.

Die verkeer wat deur S.A.-hawens gehanteer word hang af van die ligging van die hawe t.o.v. elkeen se hinterland. Suid-Afrika se landbou- en mynbouprodukte is beperk deur geografiese en klimatologiese omstandighede tot sekere gebiede en dié produkte word na die naaste hawe gestuur vir uitvoer. As ons na die S.A. hawens en Lourenco Marques kyk sien ons dat elke hawe belangrik is t.o.v. sekere produkte, nl.:

Lourenco Marques is die vernaamste uitvoerhawe vir:

Chroomerts, asbestos, steenkool en dan ook sekere produkte van Phalaborwa.

Durban is die vernaamste uitvoerhawe van:

Wattelbas en -ekstrak, olieprodukte, suiker en -produkte, mangaanerts en algemene verkeer.

Oos-Londen is die vername uitvoerhawe van:

Wol en mielies asook mielieprodukte.

Port Elizabeth is die vernaamste uitvoerhawe van:

Wol, huide en velle, ertse en delfstowwe.

Kaapstad is die vernaamste uitvoerhawe van:

Vars vrugte, koper en lood, vars groente, vleis en botter, bewerkte vrugte, groente en vis, kaas en eiers.

In Bylae $R$ word 'n ontleding gegee van verkeer deur SuidAfrikaanse hawens gehanteer.

\section{HAWETARIEWE}

Die belangrikste inkomste van hawens word verkry uit die heffing van kaaigelde op verkeer wat in- en uitgevoer word. Hierdie gelde word gebruik vir die daarstelling en onderhoud van hawebates soos breekwaters, kaaie ens.

Aangesien Durban die naaste S.A. hawe aan die Witwatersrandse industriële kompleks is, is dit ook die grootste hawe in Suid-Afrika. Om die ontwikkeling van die ander hawens en veral Oos-Londen en Port Elizabeth aan te moedig het die Spoorweë spesiale tariewe vanaf die Randse gebied na Port Elizabeth en Oos-Londen wat net ietwat hoër is as die tarief 
van die Rand na Durban. Hierdie spesiale tarief verseker 'n beter verspreiding van verkeer oor die verskillende hawens en voorkom ook opeenhoping in Durban-hawe.

Kostes en tariewe is gestandardiseer in S.A.-hawens en die volgende is die mees algemene kostes en tariewe wat deur skepe betaal word: haweregte, sleepbootkoste, loodsdienskoste, herstelwerk aan vrag, vars water, droogdokgelde, elektriese krag, kaaikraan- en dryfkraangelde ens. Daar is ook tariewe wat betaal word deur die in- en uitvoerders soos landingskoste, sorteerkoste, weeg- en meetkoste ens.

As ons nou na die res van Afrika kyk sien ons dat hulle tariewe min of meer op dieselfde grondslag gebaseer is, afhangende van die grootte van die hawe. In lande soos Algerië, Angola ens. kry ons dat daar 'n onderskeid in tariewe is wat betref oseaanvaart en kusvaart.

In verskeie lande word daar 'n verskil gemaak tussen tariewe wat betref goedere wat in- of uitgevoer word. Die tariewe in Egipte se hawens is gedeeltelik gebaseer op die tariewe wat van toepassing is in die Suezkanaal. Daar bestaan nog verskeie afwykings in verskeie lande om sekere sektore te bevorder of aan te help.

\section{SLOT}

Uit die voorgaande bespreking is dit baie duidelik dat met die uitsondering van die S.A. Spoorweë en Hawens, die spoorwegstelsels en hawens in Afrika nog in 'n stadium van ontwikkeling is, en tot nog toe nog nie veel ontwikkel het nie. Hierdie verskil tussen die S.A. Spoorweë en die vervoerstelsels in die res van Afrika staan in noue verband met die ekonomiese posisie van die verskillende lande. Daar is vroeër aangetoon dat spoorweë alleen gebou word waar die nodige vraag na vervoer bestaan en dat hierdie vraag na vervoer grotendeels bepaal word deur die ekonomie van 'n land. Indien 'n land dus ekonomies goed ontwikkel is, sal die vervoerstelsel ook tot dieselfde mate ontwikkeld wees en omgekeerd. Die res van die lande in Afrika is relatief onderontwikkel - ekonomies gesproke, en dit is dus vanselfsprekend dat die spoorweë van daardie lande nie kan vergelyk met dié van Suid-Afrika nie.

As gevolg van die feit dat die basiese faktore wat nodig 
is vir ekonomiese ontwikkeling nie in Afrika tot dieselfde mate as in Suid-Afrika aanwesig is nie, sal Suid-Afrika besmoontlik in die toekoms baie vinniger op ekonomiese gebied vooruitgaan as ander lande in Afrika. Hierdie bewering word o.a. gestaaf deur prof. S. H. Frankel in sy boek "The Economic Impact in Underdeveloped Societies" sowel as $\mathrm{dr}$. T. J. Seres in 'n artikel oor die ekonomiese infrastrukttur van lande in Afrika. So 'n verskil in die ekonomiese ontwikkeling van lande in Afrika sal dan ook meebring dat die verskil in ontwikkelingstadium tussen die S.A. Spoorweë en ander spoorwegstelsels in Afrika nog groter sal word. 'n Faktor wat egter so 'n ontwikkeling sal teenwerk is die hulpverlening van groot moondhede aan Afrikalande. Een van die eerste projekte wat met hierdie hulp aangepak word is spoorweë en dit mag dus wees dat die gaping tussen die S.A. Spoorweë en ander spoorwegstelsels sal neig om te verminder.

Johannesburg.

J. A. Kruger.

22 Junie 1966.

BYLAE A.

Spoorweë in Afrika:

$\begin{array}{lrrrr} & \begin{array}{c}\text { Personeel } \\ \text { in } \\ \text { diens }\end{array} & \begin{array}{c}\text { Spoor- } \\ \text { lengte } \\ \text { myl }\end{array} & \text { Tonmyle } & \begin{array}{c}\text { Spoor- } \\ \text { wydte }\end{array} \\ \text { Lande } & 13,829 & 2,440 & 860,000,000 & 4^{\prime} 8 \frac{1}{2} \\ \text { Algerië } & 4,772 & 485 & 108,000,000 & 3^{\prime} 33^{\prime \prime} \\ \text { Ethiopië } & 13,224 & 589 & 195,000,000 & 3^{\prime} 6^{\prime \prime} \\ \text { Ghana } & 4,325 & 316 & 260,000,000 & 3^{\prime} 6^{\prime \prime} \\ \text { Malawi } & 8,010 & 1,491 & 2,170,460,000 & 4^{\prime} 81^{\prime \prime} \\ \text { Marokko } & 29,068 & 2,599 & 4,897,768,000 & 3^{\prime \prime} 6^{\prime \prime} \\ \text { Rhodesië } & 4,000 & 732 & 224,000,000 & 3^{\prime} 3 z^{\prime \prime} \\ \text { Senegal } & 224,200 & 13,685 & 28,739,315,137 & 3^{\prime \prime} 6^{\prime \prime} \\ \text { Suid-Afrika } & 44,587 & 3,670 & 1,611,000,000 & 3^{\prime} 3 z^{\prime \prime} \\ \text { Oos-Afrika } & 31,414 & 2,961 & 1,336,000,000 & 3^{\prime} 6^{\prime \prime} \\ \text { Soedan } & 5,403 & 1,197 & 274,348,600 & 4^{\prime} 81^{\prime \prime}\end{array}$




\section{BYLAE B.}

Aantal personeellede per roetemyl:

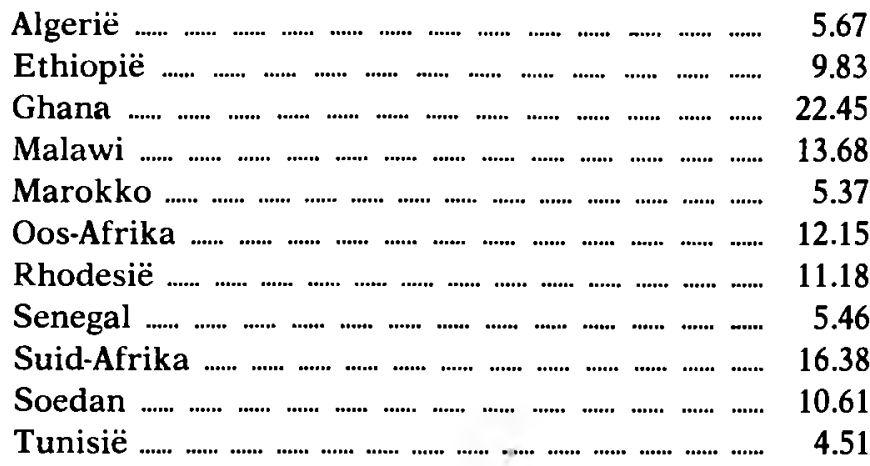

\section{BYLAE C.}

Tonmyl vervoer per personeellid:

\begin{tabular}{|c|c|}
\hline 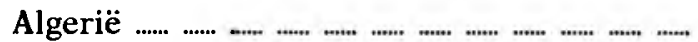 & \\
\hline jië & \\
\hline 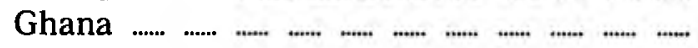 & \\
\hline 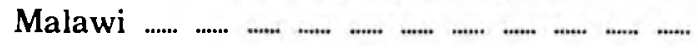 & \\
\hline 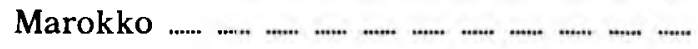 & 270 \\
\hline 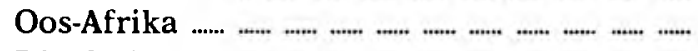 & \\
\hline 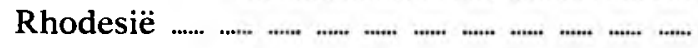 & \\
\hline 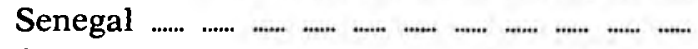 & \\
\hline ................................... & \\
\hline 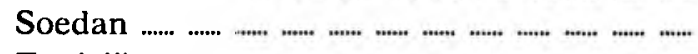 & \\
\hline & \\
\hline
\end{tabular}

\section{BYLAE D.}

Personeel van S.A.S. en H.:

Jaar

$1950 / 51$

$1951 / 52$

$1952 / 53$

$1953 / 54$

$1954 / 55$
Blank

100,159

102,226

106,095

104,697

103,659
Nie-Blank

Totaal

85,944

186,103

91,765

99,084

97,974

106,581
193,991

205,179

203,671

210,240 


$\begin{array}{llll}1955 / 56 & 107,315 & 114,412 & 221,727 \\ 1956 / 57 & 112,466 & 121,516 & 233,982 \\ 1957 / 58 & 110,506 & 122,190 & 232,696 \\ 1958 / 59 & 113,684 & 11,777 & 225,461 \\ 1959 / 60 & 109,939 & 108,010 & 217,949 \\ 1960 / 61 & 110,407 & 105,624 & 216,031 \\ 1961 / 62 & 110,598 & 103,671 & 214,269 \\ 1962 / 63 & 111,439 & 104,590 & 216,029 \\ 1963 / 64 & 113,551 & 107,549 & 221,100 \\ 1964 / 65 & 113,610 & 109,851 & 223,461 \\ 1965 / 66 & 115,042 & 111,045 & 226,087\end{array}$

BYLAE E.

Arbeidsproduktiwiteit:

\begin{tabular}{|c|c|c|c|c|c|}
\hline 离 & 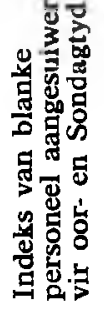 & 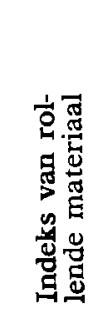 & 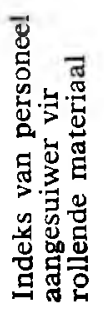 & 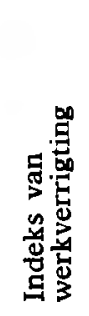 & 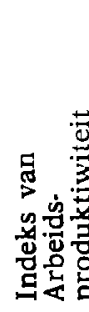 \\
\hline $1950 / 51$ & 1000 & 1000 & 1000 & 1000 & 1000 \\
\hline $1951 / 52$ & 1002 & 1029 & 1016 & 1051 & 1034 \\
\hline $1952 / 53$ & 1054 & 1068 & 1061 & 1113 & 1049 \\
\hline $1953 / 54$ & 1065 & 1105 & 1085 & 1142 & 1053 \\
\hline $1954 / 55$ & 1060 & 1138 & 1099 & 1154 & 1050 \\
\hline $1955 / 56$ & 1080 & 1181 & 1131 & 1221 & 1080 \\
\hline $1956 / 57$ & 1121 & 1219 & 1170 & 1246 & 1065 \\
\hline $1957 / 58$ & 1124 & 1257 & 1191 & 1238 & 1082 \\
\hline $1958 / 59$ & 1116 & 1306 & 1211 & 1330 & 1098 \\
\hline $1959 / 60$ & 1092 & 1337 & 1215 & 377 & 1138 \\
\hline $1960 / 61$ & 1088 & 1444 & 1266 & 1467 & 1159 \\
\hline $1961 / 62$ & 1111 & 1514 & 1313 & 1530 & 1165 \\
\hline $1962 / 63$ & 1127 & 1570 & 1349 & 1601 & 1187 \\
\hline $1963 / 64$ & 1158 & 1647 & 1403 & 1728 & 1232 \\
\hline $1964 / 65$ & 1187 & 1742 & 1465 & 1835 & 1253 \\
\hline
\end{tabular}

Voetnota: Die gebruikte metode is in ooreenstemming met dié wat deur verskillende ander spoorweë, o.m. die Duitse, Franse en Japanse spoorweë, gebruik word. 
BYLAE F.

Afrika Spoorverkeer - Tonnemaat goedere vervoer:

\begin{tabular}{|c|c|c|}
\hline Land & $\begin{array}{c}\text { Tonnemaat '000 } \\
1958 / 59\end{array}$ & $\begin{array}{c}\text { Tonnemaat '000 } \\
1963 / 64\end{array}$ \\
\hline Algerië & $6,359.5$ & - \\
\hline Angola & 519.7 & $3,957.0$ \\
\hline Oos-Afrika & $5,520.0$ & $5,408.0$ \\
\hline Egipte & - & $7,548.9$ \\
\hline Ethiopië & 254.0 & 337.3 \\
\hline Frans Kameroen & $\longrightarrow$ & 817.0 \\
\hline Frans Ekwatoriaal Afrika & 417.0 & - \\
\hline Frans Wes-Afrika & $1,421.3$ & - \\
\hline Ghana & $2,091.5$ & $1,932.1$ \\
\hline Libië & - & - \\
\hline Marokko & $11,425.7$ & $12,002.4$ \\
\hline Mosambiek & $24,566.0$ & $62,433.7$ \\
\hline Nigerië & $2,808.0$ & $2,819.0$ \\
\hline Njassaland & 502.6 & 863.2 \\
\hline Rhodesië & $11,250.7$ & $11,990.0$ \\
\hline Sierra Leone & 127.3 & 102.9 \\
\hline Suid-Afrika & $64,685.4$ & $92,261.5$ \\
\hline Soedan & $1,900.8$ & $2,695.6$ \\
\hline Togoland & - & 111.0 \\
\hline Tunisië & $4,426.6$ & $4,528.0$ \\
\hline Dahomé & - & 893.9 \\
\hline Ivoorkus & $\longrightarrow$ & 452.9 \\
\hline Liberië & $\longrightarrow$ & $3,000.0$ \\
\hline Senegal & - & $1,031.1$ \\
\hline Kongo (Brazzaville) & & $1,413.2$ \\
\hline Kongo (Leopoldville) & $9,899.9$ & $6,282.2$ \\
\hline
\end{tabular}


BYLAE G.

Afrika Spoorverkeer -

Vernaamste passasiersvervoerders in Afrika:

\begin{tabular}{|c|c|}
\hline Land & $\begin{array}{l}\text { Aandeel in } \\
\text { totale verkeer }\end{array}$ \\
\hline 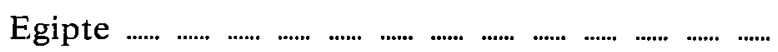 & $19.40 \%$ \\
\hline Algerië & $1.28 \%$ \\
\hline Oos-Afrika (Kenia, Oeganda en Tanganjika) ...... & $1.25 \%$ \\
\hline Ghana & $1.17 \%$ \\
\hline Marokko $\ldots \ldots \ldots \ldots \ldots$ & $0.84 \%$ \\
\hline 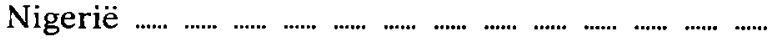 & $1.53 \%$ \\
\hline $\begin{array}{l}\text { Rhodesië } \quad \ldots \ldots \\
\ldots \ldots\end{array}$ & $0.9 \%$ \\
\hline Tunisië …... & $2.28 \%$ \\
\hline Suid-Afrika & $66.86 \%$ \\
\hline
\end{tabular}

World Railways: 1961/62. 


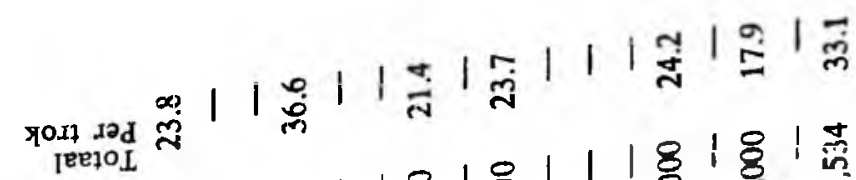

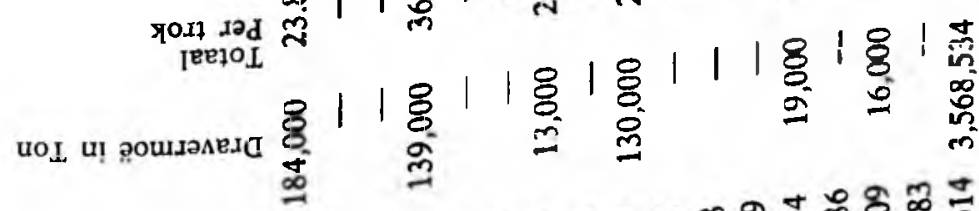

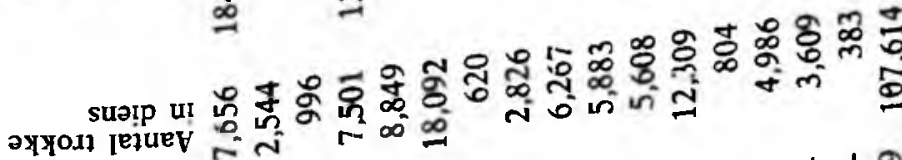

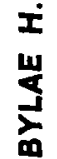

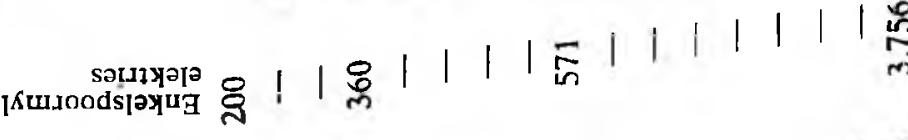

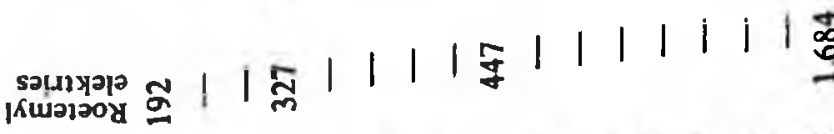

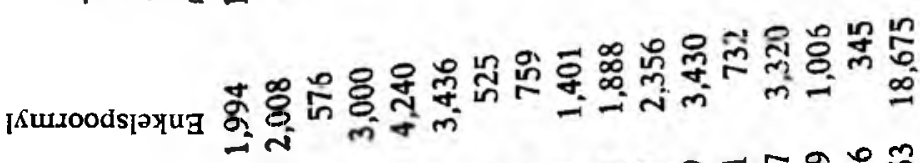

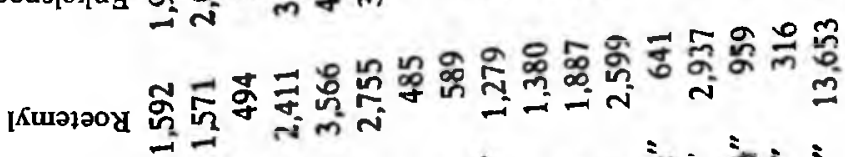

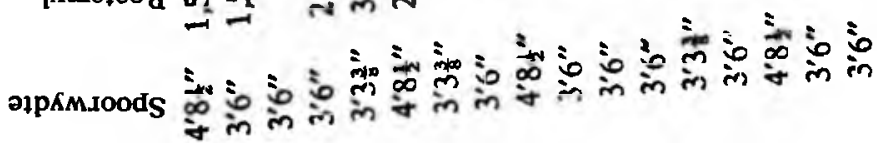

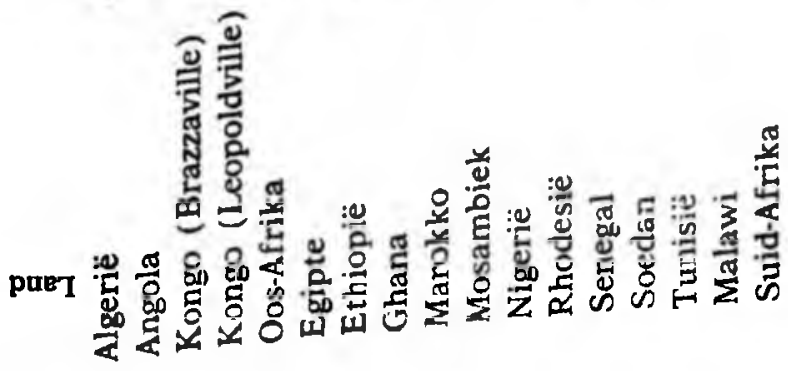


BYLAE I.

Spoorwegfinansies van spoorweë in Afrika: 1961/62:

Land

Inkomste

Bedryfs-

Land

$\mathbf{R}$

uitgawe

Angola

$14,857,527$

Kongo (Brazzaville)

$6,959,480$

$9,105,762$

verhoud.

Kameroen

$5,793,190$

$6,654,310$

61.3

Dahomé

$3,645,400$

$5,763,750$

95.7

Oos-Afrikaanse Federasie

$40,236,200$

$3,325,390$

99.0

Ghana

$9,230,800$

$34,646,200$

91.2

Mosambiek

$3,791,657$

Nigerië

$\mathrm{Njassaland}$

$30,367,000$

$8,136,800 \quad 89.4$

86.1

$3,051,400$

41.6

Rhodesië

Senegal

Rep. van S.A.

$61,842,000$

$29,033,600$

96.0

$1,878,600 \quad 61.2$

$10,448,750$

$54,960,000$

88.9

$353,865,500$

$9,458,520$

90.5

$25,184,200$

$286,691,000$

81.0

Soedan

$16,479,000$

65.4

${ }^{*}$ Bedryfsverhouding $=\frac{\text { bedryfsuitgawe }}{\text { Inkomste }}$

S.A. Spoorweë: Inkomste verdien vit vernaamste dienste:

\begin{tabular}{|c|c|c|c|c|c|c|}
\hline & $1010 / 1$ & $\%$ van & 1035136 & $\%$ van & $1064<5$ & $\%$ van \\
\hline Spoorweë: & & & & & & \\
\hline Passasiers & $4,841,708$ & 20.68 & $10,419,076$ & 14.84 & $56,367,447$ & 9.60 \\
\hline Goedere & $10,809,645$ & 46.15 & $37,910,286$ & 54.01 & $311,889,639$ & 53.13 \\
\hline Hulpdienste & 589,952 & 2.51 & $3,124,593$ & 4.45 & $29,026,440$ & 4.94 \\
\hline Tot. Spoorweë & $21,904,572$ & 93.53 & $66,109,880$ & 94.18 & $523,433,454$ & 89.14 \\
\hline Hawens & $1,507,912$ & 6.47 & $3,741,928$ & 5.33 & $29,039,000$ & 4.95 \\
\hline Lugdiens & & & 129,970 & 0.19 & $34,505,465$ & 5.91 \\
\hline Stoomskepe & & - & 290,864 & 0.30 & - & \\
\hline Groottotaal & $23,412,484$ & 100.00 & $70,191,642$ & 100.00 & $586,977,919$ & 100.00 \\
\hline
\end{tabular}


BYLAE J.

Vernaamste vitbreidingsprojekte onlangs voltooi en tans onder konstruksie:

A. Nuwe spoorlyne:

$\mathrm{Rm}$.

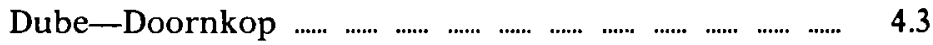

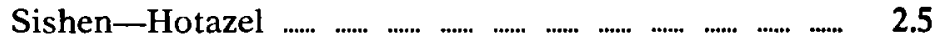

Duff's Road-Native Township .................................... 1.1

$\begin{array}{llllllllll}\text { Hoedspruit-Phalaborwa } & \ldots . . . & \ldots . . . & \ldots . . . & \ldots . . . & \ldots . . . & \ldots . . . & \ldots . . & \ldots . . . & 4.0\end{array}$

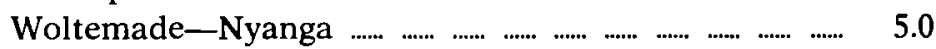

Langa-Bellville ................................................................ $\quad \begin{array}{llll} & \ldots .8\end{array}$

Delmas_Plaas Middelburg No. 39 (dist. Delmas) ..... 2.9

Fouchville-Houtkop $\quad$......................................................

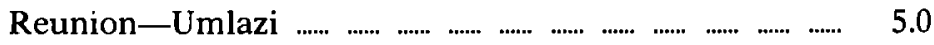

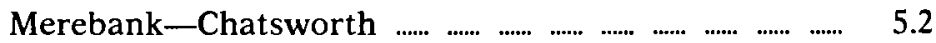

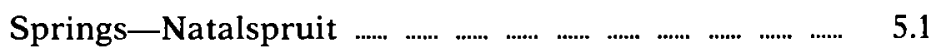

Magtiging ook verkry vir die bou van die volgende lyne:

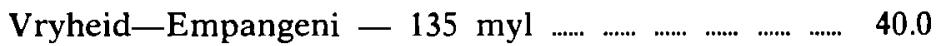

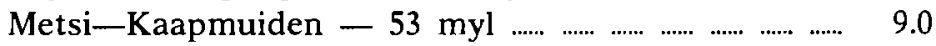

Stoffberg-Roossenekal — 23 myl ............................ $\quad 3.5$

\section{B. Verdubbeling:}

Rm.

Athlone-Dieprivier .......................................................... $\quad 2.1$

Kaapstad—Woltemade (verdriedubbeling)

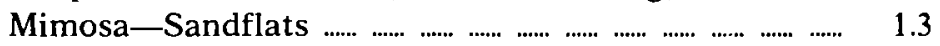

Cambridge-Blaney ........................................................ $\quad$.... 3.2

Glencoe-Newcastle ...................................................... $\quad \ldots$

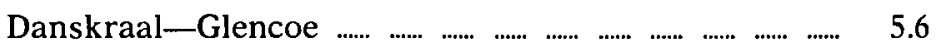

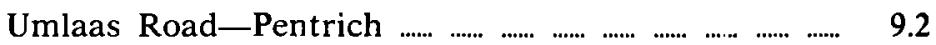

Verulam-Darnall ........................................................

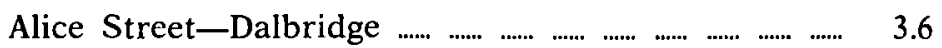

Alice Street_Duff's Road ............................................. $\quad$... 5.4

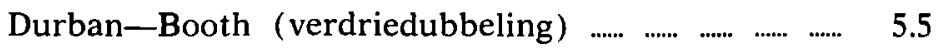

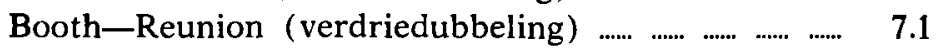

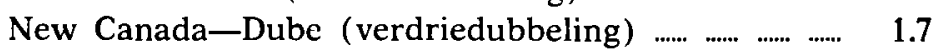




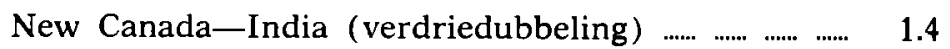

Elandsfontein-Kaalfontein (verdriedubbeling) ............ $\quad 6.2$

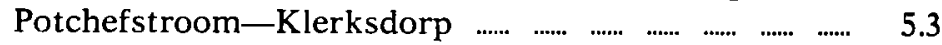

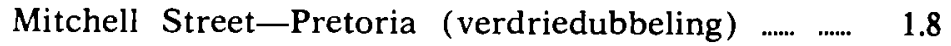

Mitchell Street-Hercules (verdriedubbeling) ........... $\quad 1.5$

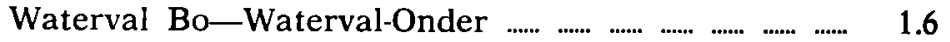

\section{Elektrifikasie:}

Rm.

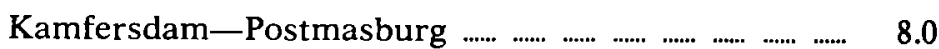

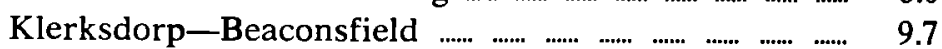

Duff's Road-Mandini ........... .......................................... $\quad$.... 7.6

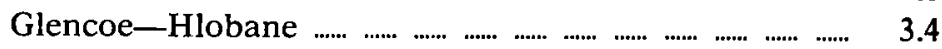

Reunion-Kelso .............................................................

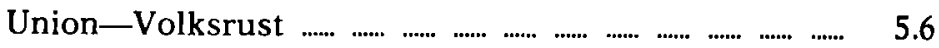

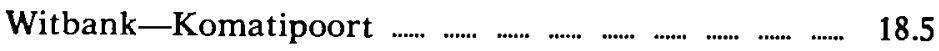

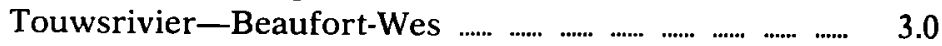

D. Ander:

Rm.

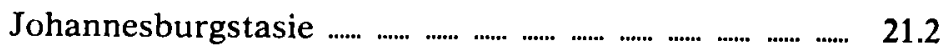

Kaapstadstasie ...................................................................... 17.1

Port Elizabethse nuwe goedereaanleg .............................. $\quad 3.4$

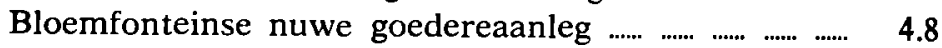

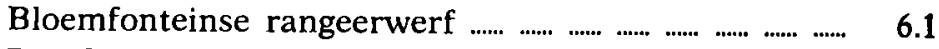

Danskraalse rangeerwerf ................................................

Kamfersdam-Postmasburg G.V.B. ............................... $\quad 1.8$

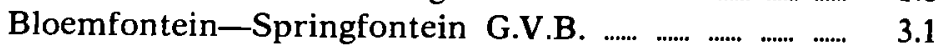

Werk het ook reeds begin aan:

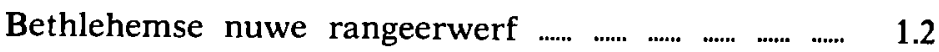

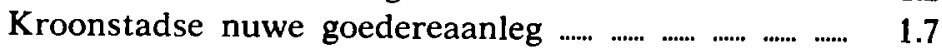

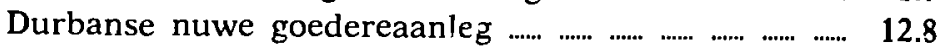

Koedoespoortse nuwe werkswinkel ................................ 15.6 
BYLAE K.

S.A. Spoorweë: Uitgawehoofde:

\begin{tabular}{|c|c|c|c|c|}
\hline & $1935 / 36$ & $\begin{array}{c}\% \text { van } \\
\text { totaal }\end{array}$ & $1964 / 65$ & $\begin{array}{c}\% \text { van } \\
\text { totaal }\end{array}$ \\
\hline Spoorweë: & & & & \\
\hline $\begin{array}{l}\text { Onderh. van spoor } \\
\text { baan en werke }\end{array}$ & $5,220,388$ & 8.20 & $53,054,329$ & 9.31 \\
\hline Rollende mat. & $7,771,268$ & 12.20 & $64,351,412$ & 11.29 \\
\hline Treinloopkoste & $10,035,894$ & 15.76 & $98,144,965$ & 17.21 \\
\hline Verkeerskoste & $8,522,128$ & 13.38 & $91,219,135$ & 16.00 \\
\hline Tot. vervoerd. & $39,315,232$ & 61.72 & $383,690,406$ & 67.30 \\
\hline Hulpdienste & $2,926,358$ & 4.59 & $29,260,116$ & 5.13 \\
\hline Rente op kap. & $10,214,266$ & 16.03 & $67,376,386$ & 11.82 \\
\hline Tot. spoorweë & $54,863,564$ & 86.14 & $507,947,594$ & 89.09 \\
\hline Hawens & $2,664,472$ & 4.18 & $18,482,714$ & 3.24 \\
\hline Stoomskepe & 202,554 & 0.32 & - & \\
\hline Lugdiens & 257,968 & 0.41 & $32,300,118$ & \\
\hline Pypleidings & - & $\ldots$ & 1,481 & \\
\hline *Aanwendingsrek. & $5,711,636$ & 8.95 & $11,406,200$ & 2.00 \\
\hline
\end{tabular}

\begin{tabular}{lllll}
\hline Groottotaal & $63,700,194$ & 100.00 & $570,138,107$ & 100.00
\end{tabular}

* Bedrae aangewend uit netto surplus vir die volgende fondse: Verbeteringsfonds, tekort in pensioen- en superannuasiefonds, fonds ter uitskakeling van spooroorgange.

BYLAE L.

Ontleding van die hawens van Suid-Afrika vitgedruk in haweton vir in- en vitvoer:

Ingevoer:

$\begin{array}{lllll}\text { Algemeen } & 1,600,000 & 1,500,000 & 480,000 & 2,500,000\end{array}$

Kunsmis $\quad 300,000 \quad 470,000$




\begin{tabular}{|c|c|c|c|c|}
\hline Swael & 37,000 & & & 105,000 \\
\hline Graan & 36,000 & 30,000 & 15,000 & 60,000 \\
\hline Hout & 82,000 & 14,000 & 30,000 & 121,000 \\
\hline Spoorwegmateriaa & 30,000 & 46,000 & 18,000 & 30,000 \\
\hline Brandolie & $1,370,000$ & 602,000 & 358,000 & $5,619,000$ \\
\hline Totaal & $3,455,000$ & $2,192,000$ & 901,000 & $8,905,000$ \\
\hline \multicolumn{5}{|l|}{ Uitgevoer: } \\
\hline Algemeen & 760,000 & 160,000 & 72,000 & 860,000 \\
\hline $\begin{array}{l}\text { Mielies en -prod. } \\
\text { Graan (be- } \\
\text { halwe mielies) }\end{array}$ & 151,000 & 22,000 & 58,000 & 783,000 \\
\hline Ander produkte & 113,000 & 45,000 & 21,000 & 233,000 \\
\hline Wol & 51,000 & 121,000 & 77,000 & 81,000 \\
\hline Velle & 12,000 & 31,000 & & 25,000 \\
\hline \multicolumn{4}{|c|}{ Wattelbas en -ekstrak } & 101,000 \\
\hline Suiker & & & & 890,000 \\
\hline Sitrusvrugte & 224,000 & 145,000 & 47,000 & 111,000 \\
\hline Sagtevrugte & 293,000 & 42,000 & & \\
\hline Gedroogte vrugte & $\mathbf{8 , 0 0 0}$ & & & \\
\hline $\begin{array}{l}\text { Ander soort vrugte } \\
\text { Steenkool: }\end{array}$ & Steenkool: & & 5,000 & \\
\hline $\begin{array}{l}\text { Steenkoor: } \\
\text { Buiteland }\end{array}$ & & & & 692,000 \\
\hline Gebunker & 112,000 & & & \\
\hline Brandolie & 294,000 & & & $3,309,000$ \\
\hline $\begin{array}{l}\text { Ertse en ander } \\
\text { delfstowwe }\end{array}$ & 79,000 & $1,744,000$ & 42,000 & $1,190,000$ \\
\hline Totaa & $2,097,000$ & 310,000 & 322,000 & $8,411,000$ \\
\hline
\end{tabular}

BYLAE M.

Ontleding van verkeer in Suid-Afrikaanse hawens vitgedruk in haweton vir in- en vitvoer*

$1924 / 24 \quad 1934 / 35 \quad 1954 / 55 \quad 1964 / 65$

Ingevoer:

Algemeen $\quad 1,777,545 \quad 1,871,767 \quad 4,456,475 \quad 6,374,291$

$\begin{array}{lrrrr}\text { Hout } & 273,989 & 253,737 & 434,204 & 267,851\end{array}$ 


$\begin{array}{lrrrr}\text { Graan } & 164,402 & 27,932 & 233,082 & 142,071 \\ \text { Ander produkte } & 23,945 & 7,894 & 13,278 & \\ \text { Steenkool } & 19,168 & 121 & & \\ \text { Spoorwegmat. } & 346,181 & 143,691 & 324,037 & 125,668 \\ \text { Oliebrandstof } & 74,433 & 500,824 & 2,892,734 & 8,302,297 \\ \text { Ontploffingst. } & 370 & 62 & & \\ \text { Kunsmis } & & & & 780,953 \\ \text { Swael } & & & & 143,646\end{array}$

\begin{tabular}{lllll}
\hline Totaal & $2,680,033$ & $2,806,028$ & $8,353,810$ & $16,136,777$ \\
\hline
\end{tabular}

\section{Uitgevoer:}

\begin{tabular}{|c|c|c|c|c|}
\hline Algemeen & 261,675 & 241,717 & 793,321 & $2,274,339$ \\
\hline Hout & 2,903 & 1,561 & 20,804 & 8,509 \\
\hline Mielies en -prod. & 218,791 & 25,797 & 702,446 & $1,016,647$ \\
\hline \multicolumn{5}{|l|}{ Graan (be- } \\
\hline halwe mielies) & 13,629 & 2,185 & 57,935 & 151,402 \\
\hline Ander produkte & 296,569 & 517,004 & 461,836 & 458,770 \\
\hline Wol & 205,474 & 329,431 & 336,072 & 335,747 \\
\hline Vrugte, sitrus & 26,931 & 129,529 & 321,210 & 529,283 \\
\hline \multicolumn{5}{|l|}{ Vrugte, } \\
\hline ander soorte & 25,301 & 85,363 & 57,294 & 5,683 \\
\hline Gedroogde vrugte & & & 7,605 & 7,515 \\
\hline Sagte vrugte & & & 157,959 & 335,718 \\
\hline \multicolumn{5}{|l|}{ Steenkool: Na an- } \\
\hline Na buiteland 1 , & $1,521,265$ & 720,053 & 326,892 & 692,342 \\
\hline Gebunker & $1,664,212$ & 730,862 & 175,149 & 112,163 \\
\hline Oliebrandstof & 8,631 & 42,665 & 817,309 & $3,612,334$ \\
\hline Ertse en minerale & 73,991 & 39,982 & 700,428 & $3,322,126$ \\
\hline \multicolumn{3}{|c|}{ Velle } & 64,268 & 77,825 \\
\hline \multicolumn{3}{|c|}{ Wattelbas en -ekstrak } & 122,156 & 109,193 \\
\hline \multicolumn{3}{|c|}{ Suiker } & 368,817 & 890,928 \\
\hline & & $2,867,187$ & $5,495,334$ & $13,943,000$ \\
\hline
\end{tabular}

* Die volgende hawens word ingesluit: Tafelbaai, Mosselbaai, Port Elizabeth, Oos-Londen, Durban en Walvisbaai.

Gegewens vir 1944/45 is nie beskikbaar nie. 
BYLAE N.

Belangrikste hawens in Afrika:

\begin{tabular}{|c|c|c|c|c|}
\hline \multirow[b]{2}{*}{ Land en Hawe } & \multirow[b]{2}{*}{ Datum } & \multirow{2}{*}{$\begin{array}{l}\text { Aantal } \\
\text { Skepe }\end{array}$} & \multicolumn{2}{|c|}{ Tonnemaat } \\
\hline & & & In & Uit \\
\hline \multicolumn{5}{|l|}{ Algerië: } \\
\hline Algiers & 1961 & 5,094 & $2,922,852$ & $1,257,144$ \\
\hline Bougie & $61 / 62$ & 1,115 & 231,174 & $8,778,772$ \\
\hline \multicolumn{5}{|l|}{ Angola: } \\
\hline Lobito & 1960 & 1,032 & 320,243 & $1,371,148$ \\
\hline \multicolumn{5}{|l|}{ Kameroen Rep. } \\
\hline Duala & 1961 & 889 & 496,233 & 441,171 \\
\hline \multicolumn{5}{|l|}{ Kongo Rep.: } \\
\hline Pointe Noire & 1962 & 854 & 402,316 & 469,025 \\
\hline \multicolumn{5}{|l|}{ Ghana: } \\
\hline Takoradi & 1962 & 1,429 & 737,661 & $1,618,704$ \\
\hline \multicolumn{5}{|l|}{ Liberië: } \\
\hline Monrovia & 1963 & - & 417,170 & $2,371,268$ \\
\hline \multicolumn{5}{|l|}{ Libië: } \\
\hline Tripoli & 1962 & 1,620 & 365,000 & 365,000 \\
\hline \multicolumn{5}{|l|}{ Marokko: } \\
\hline Ceuta & 1961 & 5,734 & van $15,235,00$ & 00 ton \\
\hline Kenitra & 1962 & 806 & 127,656 & 406,071 \\
\hline \multicolumn{5}{|l|}{ Nigerië: } \\
\hline Koko & $62 / 63$ & 2,174 & $2,340,404$ & $1,180,842$ \\
\hline Port Harcourt & $62 / 63$ & 939 & 780,274 & 708,747 \\
\hline \multicolumn{5}{|l|}{ Mosambiek: } \\
\hline Beira & 1962 & 1,059 & $3,313,269$ & ton hanteer \\
\hline Lour. Marques & 1962 & 1,763 & $2,922,565$ & $3,491,340$ \\
\hline \multicolumn{5}{|l|}{ Sierra Leone: } \\
\hline Freetown & 1960 & 1,434 & 291,777 & 70,442 \\
\hline \multicolumn{5}{|l|}{ Suid-Afrika: } \\
\hline Kaapstad & $61 / 62$ & 6,242 & $2,389,983$ & $2,153,926$ \\
\hline Durban & $61 / 62$ & 3,998 & $4,583,687$ & $5,888,264$ \\
\hline Oos-Londen & $62 / 63$ & 1,379 & 782,841 & 729,062 \\
\hline Port Elizabeth & $61 / 62$ & 1,657 & $1,290,470$ & $1,116,454$ \\
\hline Walvisbaai & $61 / 62$ & 412 & 316,514 & 588,799 \\
\hline \multicolumn{5}{|l|}{ Soedan: } \\
\hline Port Soedan & 1961 & 1,291 & $1,151,002$ & 649,581 \\
\hline
\end{tabular}


Tanganjika:

$\begin{array}{ccccr}\begin{array}{c}\text { Dar-es-Salaam } \\ \text { Tunisië: }\end{array} & 1961 & 1,095 & 468,588 & 266,895 \\ \text { Tunis } & 1960 & 2,124 & 962,227 & 1,811,970\end{array}$

\section{BIBLIOGRAFIE}

Lys van geraadpleegde bronne vir verdere naslaandoeleindes:

Boeke:

Ashton, H.: Railroad cost in relation to the volume of traffic.

Beckman, MacQuire and Winston: Studies in the Economics of Transportation.

Bigham, T. C. and Roberts, M. J.: Transportation Principles and Problems. Clark, W. M.: The Management of the S.A. Railways.

Dunn, S. O.: Government Ownership of Railways.

Faulks, R. W.: Elements of Transport.

Foster, C. D.: The Transport Problem.

Frankel, S. H.: Railway Policy in South Africa.

Hazlewood, A.: Rail and Road in East Africa.

Hoy, W. W.: State ownership of Railways.

Meyer, Peck, Stenason and Swick: The Economics of Competition in Transportation industries.

Morgan, F. W.: Ports and Harbours.

Schumer, L. A.: The elements of Transport.

Troxel, E.: Economics of Transport.

Verburgh, C.: The South African Transportation Policy.

Wedgewood, R. L. \& Wheeler, J. E.: International Rail Transport.

Jaarboeke, jaarverslae en ander verslae:

The International Railway Journal: Statistical Year Book - Bureau of Statistics, Pretoria.

International Railway Statistics: International Union of Railways.

World Railways: A world-wide survey of Railway Operation and equipment. Edited and compiled by: Henry Sampson.

Ports of the World: Published by Shipping World and World Shipbuilding.

Kaarte en Statistieke nr. 1-10: Afrika-Instituut.

Verslag van die Komitee insake Spoorwegtariefbeleid en Nywerheidsvestiging in Suid-Afrika. Johannesburg, April 1964.

Jaarverslae van Hoofbestuurders van Spoorweë in Afrika. 